\title{
Nitrogen compounds emission and deposition in West African ecosystems: comparison between wet and dry savanna
}

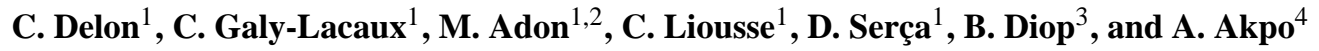 \\ ${ }^{1}$ Laboratoire d'Aérologie, UMR 5560, Université de Toulouse and CNRS, Toulouse, France \\ ${ }^{2}$ Laboratoire de Physique de l'Atmosphere, Abidjan, Côte d'Ivoire \\ ${ }^{3}$ Université de Bamako, Mali \\ ${ }^{4}$ Université Abomey Calavi, Cotonou, Bénin \\ Correspondence to: C. Delon (claire.delon@ aero.obs-mip.fr)
}

Received: 28 June 2011 - Published in Biogeosciences Discuss.: 21 July 2011

Revised: 11 November 2011 - Accepted: 21 December 2011 - Published: 18 January 2012

\begin{abstract}
Surface emission and deposition fluxes of reactive nitrogen compounds have been studied in five sites of West Africa during the period 2002 to 2007. Measurements of $\mathrm{N}$ deposition fluxes have been performed in IDAF sites representative of main west and central African ecosystems, i.e., 3 stations in dry savanna ecosystems (from $15^{\circ} \mathrm{N}$ to $12^{\circ} \mathrm{N}$ ), and 2 stations in wet savanna ecosystems (from $9^{\circ} \mathrm{N}$ to $6^{\circ} \mathrm{N}$ ). Dry deposition fluxes are calculated from surface measurements of $\mathrm{NO}_{2}, \mathrm{HNO}_{3}$ and $\mathrm{NH}_{3}$ concentrations and simulated deposition velocities, and wet deposition fluxes are calculated from $\mathrm{NH}_{4}^{+}$and $\mathrm{NO}_{3}^{-}$concentration in samples of rain. Emission fluxes are evaluated including simulated NO biogenic emission from soils, emissions of $\mathrm{NO}_{\mathrm{x}}$ and $\mathrm{NH}_{3}$ from biomass burning and domestic fires, and volatilization of $\mathrm{NH}_{3}$ from animal excreta. This paper is a tentative to understand the eventual impact of the monsoon variability from year to year, with the natural variability of local sources, on the emission and deposition $\mathrm{N}$ fluxes, and to compare these evolutions between dry and wet savanna ecosystems. In dry savanna ecosystems where the rain season lasts mainly from June to September, the occurence of rain correlates with the beginning of emission and deposition fluxes. This link is less obvious in wet savanna ecosystems (wet season mainly from May to October), where the surface is less submitted to drastic changes in terms of water content. Whatever the location, the natural variability of rain from year to year does not exceed $15 \%$, and the variability of emission and deposition magnitude ranges between $15 \%$ and $28 \%$. While quasi providing the same total $\mathrm{N}$ budget, and due to the presence of different types of soils and vegetation, wet and dry savanna do not present the same distribution in emission and deposition fluxes contributions: in dry savanna, the emission is
\end{abstract}

dominated by ammonia volatilization, and the deposition is dominated by the dry contribution. In wet savanna, emission is equally distributed between ammonia volatilization, emissions from biomass burning and natural $\mathrm{NO}$ emissions from soils, and wet and dry deposition are equivalent. Due to the scarcity of available data on the African continent, and despite the numerous uncertainties resulting from the different calculations and assumptions, this work is a combination of data from different origins (surface measurements, satellite and modelling) to document the atmospheric Nitrogen cycle in tropical regions.

\section{Introduction}

The vast majority of $\mathrm{N}$ in the atmosphere is $\mathrm{N}_{2}$, which is biologically unavailable to most organisms. $\mathrm{N}$ must be converted from $\mathrm{N}_{2}$ to reactive $\mathrm{N}\left(\mathrm{N}_{\mathrm{r}}\right)$ (Chen et al., 2010). Most biological $\mathrm{N}$ fixation (BNF) in terrestrial systems occurs in tropical regions (Galloway et al., 2008), and the response of these systems to additional $\mathrm{N}$ inputs could result in rapid $\mathrm{N}$ losses to air and water (Matson et al., 1999). Chen et al. (2010) have estimated that the mean BNF rate in savannas was $18.6 \mathrm{kgNha}^{-1} \mathrm{yr}^{-1}$. The flux of a trace gas between the soil and the atmosphere is the result of three basic processes: production, consumption and transport. In the case of $\mathrm{Nr}$, production leads to emission of $\mathrm{N}$ compounds such as $\mathrm{NO}$ and $\mathrm{NH}_{3}$, and consumption is preceded by transport and deposition of compounds such as gases $\left(\mathrm{NH}_{3}, \mathrm{NO}_{2}, \mathrm{HNO}_{3}\right.$, Peroxy Acetyl Nitrates,...), and particles $\left(\mathrm{pNH}_{4}^{+}, \mathrm{pNO}_{3}^{-}\right)$. The atmospheric nitrogen budget depends on emission and deposition fluxes both as reduced and oxidized compounds. 
The deposition flux is both driven by wet and dry deposition processes. Direct methods (eddy covariance, gradient method) and indirect methods (inferential method combined to concentrations measurements) are available to determine dry deposition fluxes. The DEBITS (DEposition of Biogeochemically Important Trace Species) committee in charge of deposition studies in IGAC (International Global Atmospheric Chemistry) has decided to use indirect dry deposition fluxes determination in tropical sites, because of difficulties to operate sophisticated direct methods of fluxes measurements in remote sites (Wolff et al. (2010); Sutton et al. (2007)). Recording to this, dry deposition fluxes are here estimated using the inferential method, that is combining measurements of concentrations and modelling of deposition velocity according to the resistance analogy (Wesely (1989); Zhang et al. (2003) and references therein).

IDAF (IGAC/DEBITS/Africa) network started in 1995 in tropical Africa. The major objectives of IDAF are to measure wet and dry deposition fluxes, to identify the relative contribution of natural and anthropogenic sources, and the factors regulating these fluxes. The IDAF activity is based on high quality measurements of atmospheric chemical data (gaseous, precipitation and aerosols chemical composition) on the basis of a multi-year monitoring (http://idaf.sedoo.fr).

Natural emissions from soils are produced by microbial processes (nitrification/denitrification), and several modelling approaches have allowed global and regional estimates of NO (Yienger and Levy (1995); Butterbach-Bahl et al. (2001); Stohl et al., 1996) and $\mathrm{NH}_{3}$ (Bouwman et al., 1997) emissions from soils. A dynamic approach of caculating NO fluxes from soils, has been developed (Delon et al., 2007) and applied in the Sahel region (Delon et al., 2008). Compared to existing inventories, the main advantage of this approach is to be coupled on line with meterological parameters.

Anthropogenic emissions of $\mathrm{N}$ compounds in the atmosphere have been widely studied, often in temperate regions. At the global scale, reactive $\mathrm{N}$ production continues to increase every year, dominated by agricultural activities, fossil fuel energy, as well as biofuels, leading to a global estimate of $187 \mathrm{Tgyr}^{-1}$ in 2005 (Galloway et al., 2008). In tropical regions, the estimate of biogenic $\mathrm{N}$ emitted and deposited is less easy to calculate, because of a lack of data.

In West Africa, meteorological variations are determined by those of the West African Monsoon (WAM). The ITCZ (InterTropical Convergence Zone) is the primary factor controlling directly the rainfall over West Africa. In boreal winter, the continent is dry (the ITCZ is around $5^{\circ} \mathrm{N}$ ). It reaches its northernmost position (between 10 and $12^{\circ} \mathrm{N}$ ) in August before retreating to the south (Lebel et al., 2009). The resulting typical rainfall cycle involves a 3 to 6 months rainy season, depending on the latitudinal position. In theory, more rain will allow an increase in the vegetation available for grazing, i.e. a better quality and higher quantity of food for animals, which will induce more $\mathrm{N}$ in animal manure, more $\mathrm{NH}_{3}$ from volatilization and $\mathrm{NO}$ emission from soils, and therefore more wet and dry deposition of Nitrogen compounds. The volatilization of $\mathrm{NH}_{3}$ and other species will be retrieved in the rains, and scavenged by the wet deposition, which will further increase the $\mathrm{NH}_{4}^{+}$availability in soils, and again the $\mathrm{NH}_{3}$ volatilization and $\mathrm{NO}$ emission from soils.

In this study, a first attempt at estimating the nitrogen emission and deposition fluxes is made for the period 2002 to 2007 , through measurements and simulations at five stations of the IDAF network situated in dry and wet savanna ecosystems, as shown in Fig. 1.

In a preceeding work detailed in Delon et al. (2010), the Sahel atmospheric nitrogen budget for the year 2006 was made through measurements and simulations. The method used in the present study is the same as the one detailed in Delon et al. (2010), but applied on a longer period (2002 to 2007) and for 2 more sites located in wet savanna areas. The present work allows a comparison between two different nitrogen emitting ecosystems, for different years and different points at the local scale. The interannual approach (compared to the single year approach made for 2006) helps to study the reproducibility of nitrogen emission and deposition fluxes linked to the WAM seasonal cycle, and to compare the eventual impact of the WAM variability from year to year, with the natural variability of local sources. The present paper is actually a continuation of Delon et al. (2010), as it uses the same methods for the calculation of fluxes, but with the integration of the description of wet savanna emission and deposition fluxes, and the comparison with dry savanna ecosystems in terms of contribution of different sources.

In the following, we will give details on the calculation of $\mathrm{N}$ compounds emission fluxes from biomass burning $\left(\mathrm{NO}_{\mathrm{x}}\right.$ and $\mathrm{NH}_{3}$ ), domestic fires $\left(\mathrm{NO}_{\mathrm{x}}\right.$ and $\left.\mathrm{NH}_{3}\right)$, soils (NO) and volatilization $\left(\mathrm{NH}_{3}\right)$, and on $\mathrm{N}$ compounds dry $\left(\mathrm{HNO}_{3}, \mathrm{NO}_{2}\right.$, $\left.\mathrm{NH}_{3}\right)$ and wet deposition fluxes $\left(\mathrm{NH}_{4}^{+}\right.$and $\left.\mathrm{NO}_{3}^{-}\right)$. In a second time, we will try to give an analysis of inter and intra annual variation of emission and deposition fluxes along a latitudinal transect (from $6.1^{\circ} \mathrm{N}$ to $15.1^{\circ} \mathrm{N}$ ), for the period 2002 to 2007. This budget is not exhaustive, because measurements do not include all $\mathrm{N}$ compounds. Non reactive $\mathrm{N}$ compounds $\left(\mathrm{N}_{2}, \mathrm{~N}_{2} \mathrm{O}, \mathrm{N}_{2} \mathrm{O}_{5}\right)$ are not included in the budget (we only consider the atmospheric reactive $\mathrm{N}$ compounds). $\mathrm{N}_{2} \mathrm{O}$ emissions from savanna soils account for $16 \%$ of the global production of $\mathrm{N}_{2} \mathrm{O}$ (Brummer et al., 2008), but $\mathrm{NO}$ has a higher chance than $\mathrm{N}_{2} \mathrm{O}$ to escape from sandier soils (Meixner and Yang, 2004), especially if Water Filled Pore Space (WFPS) is inferior to $50 \%$ (Bouwman et al., 2002), which is the case of most of the sites studied in this work. For $\mathrm{N}_{2}$, it is relatively well established that emissions are favoured by a WFPS superior to $70 \%$ and for loam and clay loam soils (Loubet et al., 2011). The contribution of $\mathrm{N}_{2}$, $\mathrm{N}_{2} \mathrm{O}$, and $\mathrm{N}_{2} \mathrm{O}_{5}$ can therefore be considered as negligible in semi arid and sandy sites with low soil humidity, whereas in other parts of West Africa it will introduce a gap in the budget if they are not quantified. 


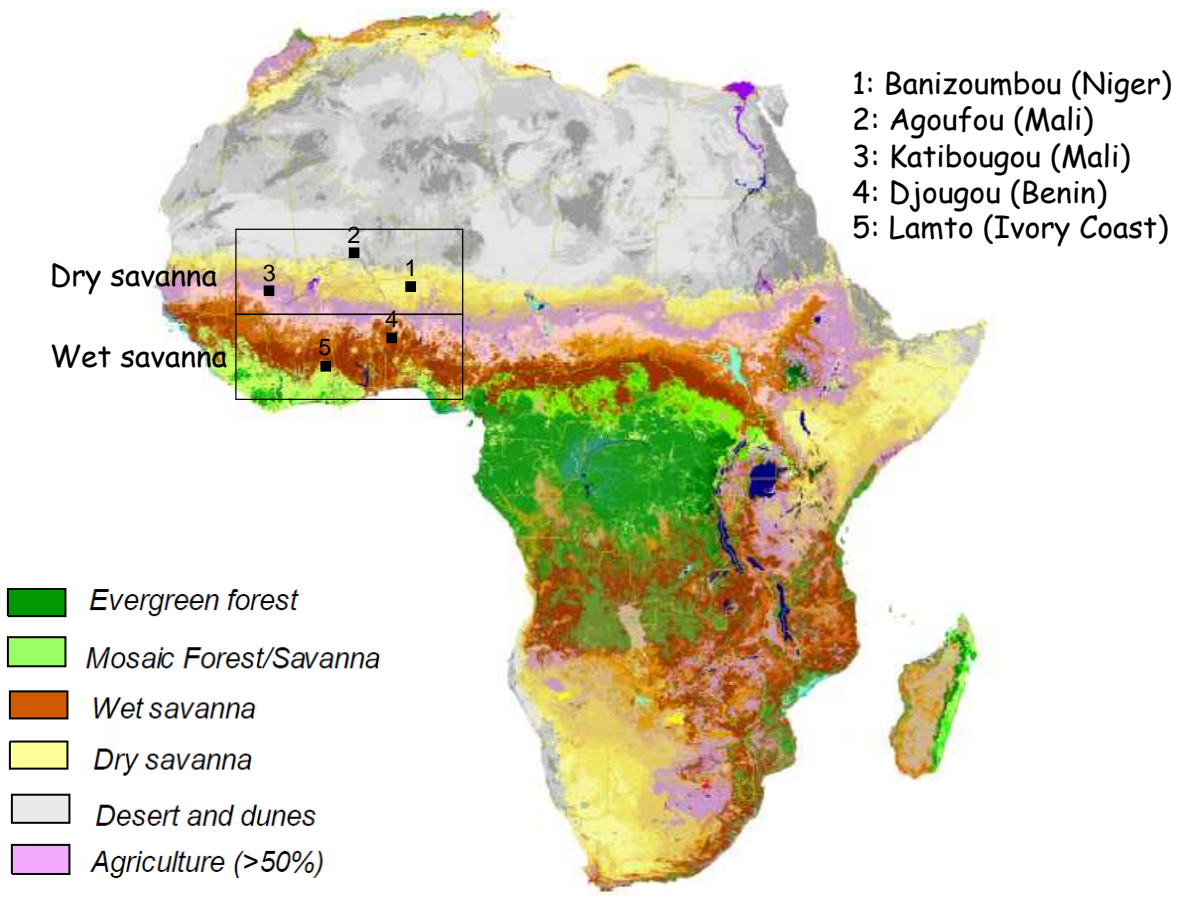

Fig. 1. Location of the stations involved in the IDAF network. Only the five first stations are included in the present study.

Organic compounds such as PAN are also omitted from this budget, assuming that they are converted into $\mathrm{NO}_{2}$ at high temperatures (Munger et al., 1998). Particulate compounds are not taken into account in the dry deposition flux calculation, because concentrations measured on sites are negligible compared to gas concentrations (Galy-Lacaux, personnal communication, 2011). However, major reactive $\mathrm{N}$ compounds sources and sinks are included to try to calculate the budget. The approach is mostly based on modelling (only nitrogen concentrations in gas and rains are measured), leading to large uncertainties and to results difficult to check, but with the idea to give an insight on rather known processes occurring in little known regions with specific environmental conditions.

We recall that all the description of materials and methods have already been written in Delon et al. (2010), but a brief summary will be given in the following paragraphs.

\section{Materials and methods}

\subsection{Presentation of measurement sites}

The study will focus on 5 stations of the IDAF network, with geographic and climatic presentation in Table 1: 3 stations are located in dry savanna: Agoufou (Mali), Banizoumbou (Niger), Katibougou (Mali), and 2 stations are located in wet savanna: Djougou (Benin), and Lamto (Ivory Coast). In Agoufou and Djougou, data have been collected from 2005 till today (but presented here from 2005 to 2007), and in Ban- izoumbou, Katibougou and Lamto, data are available from 1998 till today (but presented from 2002 to 2007).

In Table 1, mean annual rainfall is calculated from TRMM (Tropical Rainfall Measurement Mission)-3B42 data in mm, from 2002 to 2007, and compared to local site measurements. The TRMM rainfall estimates are based on combined calibrated microwave and infrared precipitation estimates with a rescaling to monthly gauge data (Boone et al., 2009). Agoufou presents $482( \pm 81) \mathrm{mm}$ of annual rain, Banizoumbou $(664( \pm 86) \mathrm{mm})$, Katibougou $(720( \pm 117) \mathrm{mm})$, Djougou $(1115( \pm 150) \mathrm{mm})$, and Lamto, the southernmost position, $1100( \pm 101) \mathrm{mm}$. Annual means and standard deviations of precipitation are calculated for the 2002-2007 period, in a $5^{\circ}$ window around each site. Compared to local measurements, we found that TRMM-3B42 data overestimates local measurements by $25 \%$ in dry savanna areas, and underestimates them by $15 \%$ in wet savannas. TRMM-3B 42 data have also been used as precipitation forcing for the simulation of deposition velocities and NO emission from soils (presented below).

Tables 2 and 3 give informations on soil types and vegetation characteristics for each station, as well as land use and livestock population. These informations have been extracted from Mougin et al. (2009) for Agoufou, from Boulain et al. (2009); Serça et al. (1998) and Leroux at al. (1995) for Banizoumbou, from Adon et al. (2010) and Kaptué et al. (2010) for Katibougou and Djougou, and from Yoboué et al. (2005) and Adon et al. (2010) for Lamto. 
Table 1. Presentation of the measurement sites. Mean annual precipitation is calculated from TRMM (see text for details) and local measurements. WS $=$ Wet Season. DS = Dry Season.

\begin{tabular}{|c|c|c|c|c|c|}
\hline Name & location & Country (region) & Climate & $\begin{array}{c}\text { Annual Precip. } \\
\text { mm (simul/meas.) }\end{array}$ & $\begin{array}{c}\text { Annual Temp. } \\
{ }^{\circ} \mathrm{C}\end{array}$ \\
\hline Agoufou & $15.3^{\circ} \mathrm{N}, 1.5^{\circ} \mathrm{W}$ & Mali (Mopti) & $\begin{array}{l}\text { Sahelian } \\
\text { WS: June-September } \\
\text { DS: October-May }\end{array}$ & $482 / 366$ & 30 \\
\hline Banizoumbou & $13.3^{\circ} \mathrm{N}, 2.4^{\circ} \mathrm{E}$ & Niger (Dosso) & $\begin{array}{l}\text { Sahelian } \\
\text { WS: June-September } \\
\text { DS: October-May }\end{array}$ & $664 / 463$ & 30 \\
\hline Katibougou & $12.5^{\circ} \mathrm{N}, 7.3^{\circ} \mathrm{W}$ & Mali (Koulikoro) & $\begin{array}{l}\text { Soudano-Sahelian } \\
\text { WS: June-September } \\
\text { DS: October-May }\end{array}$ & $720 / 765$ & 28 \\
\hline Djougou & $9.7^{\circ} \mathrm{N}, 1.7^{\circ} \mathrm{E}$ & Benin (Atakora) & $\begin{array}{l}\text { Soudano-Guinean } \\
\text { WS: April-October } \\
\text { DS: November-March }\end{array}$ & $1115 / 1250$ & 27 \\
\hline Lamto & $6.1^{\circ} \mathrm{N}, 5^{\circ} \mathrm{W}$ & Ivory Coast () & $\begin{array}{l}\text { Guinean } \\
\text { WS: April-October } \\
\text { DS: November-March }\end{array}$ & $1100 / 1300$ & 28 \\
\hline
\end{tabular}

Table 2. Presentation of the measurement sites: Soil and vegetation types.

\begin{tabular}{|c|c|c|c|c|}
\hline Name & Vegetation classification & Dominant vegetation type & Min-max LAI $\left(\mathrm{m}^{2} \mathrm{~m}^{-2}\right)$ & Soil types \\
\hline Agoufou & Dry savanna & $\begin{array}{l}\text { Open woody savanna } \\
\text { Cenchrus biflorus, Aristida Mutabilis } \\
\text { Zornia Glochidiata, Tragus Berteronianus }\end{array}$ & $0-1.8$ & $\begin{array}{l}\text { Fixed dunes } \\
\text { Sandy plains }\end{array}$ \\
\hline Banizoumbou & Dry savanna & $\begin{array}{l}\text { Tiger bush - fallow bush } \\
\text { Zornia Glochidiata, Guiera Senegalensis } \\
\text { Cenchrus prieurii }\end{array}$ & $0-1.7$ & Sandy soils \\
\hline Katibougou & Dry savanna & Deciduous shrubs & $0.3-2$ & Sandy soils \\
\hline Djougou & Wet savanna & $\begin{array}{l}\text { Deciduous shrubland with sparse trees } \\
\text { Hyparrhenia involucrata, Andropogon fatigiatus }\end{array}$ & $0.5-2.5$ & Sandy soils \\
\hline Lamto & Wet savanna & $\begin{array}{l}\text { Gallery forest mosaic } \\
\text { Hyparrhenia diplandra, Andropogon schirensis }\end{array}$ & $2.5-4$ & Ferrugineous soils \\
\hline
\end{tabular}

The type of vegetation growing on site has an important effect on biogenic NO emission from soils: nutrient poor savanna ecosystems of Agoufou and Banizoumbou (and in a less extent in Katibougou) are characterized by low denitrification potentials and relatively high nitrate accumumation. Substantial NO emissions in dry savanna ecosystems are most likely related to nitrification processes, whereas low potential of nitrification and denitrification rates in Lamto may be partly responsible of low NO fluxes (Leroux at al., 1995). The microbial activity has been studied in Lamto and Banizoumbou by Serça et al. (1998), showing very different carbon mineralization potential and potential net accumulation of ammonium between the two sites (very low in Ban- izoumbou, maximum in Lamto), whereas nitrate accumulation was equivalent in the two sites. That study did not find any significant correlation between nitrate accumulation and NO emissions.

Low nitrification rates in wet savanna ecosystem could be due to inhibition of nitrifier growth and/or functionality by specific compounds excluded by the roots of the graminea (Munro, 1966). The main herbaceaous vegetation on site in Lamto (Serça et al., 1998)) and Djougou (J. Harris and Z. Sevigona, personal communication, 2006) is hyparrhenia, and is considered as a nitrifier inhibitor. 
Table 3. Presentation of the measurement sites: Land use and population. $C=$ Cattle, $S=$ Sheep, $G=$ Goats. IPR $=$ Institut Polytechnique Rural.

\begin{tabular}{|c|c|c|c|c|}
\hline Name & Land use & Fertilisation & $\begin{array}{l}\text { Livestock } \\
\text { head.km }{ }^{-2}\end{array}$ & $\begin{array}{l}\text { Human population } \\
\mathrm{Nb} \text { people. } \mathrm{km}^{-2}\end{array}$ \\
\hline Agoufou & Main rain-fed crop: millet & Organic & $\begin{array}{l}\mathrm{C}: 24, \mathrm{~S}: 16, \mathrm{G}: 19 \\
\text { Close to a wet point } \\
\text { High grazing pressure }\end{array}$ & 16.7 \\
\hline Banizoumbou & Rain-fed crop: Millet, Sorghum & Organic & $\begin{array}{l}\text { C:22, S:21, G:27 } \\
\text { Close to a wet point } \\
\text { High grazing pressure }\end{array}$ & 45 \\
\hline Katibougou & Rain-fed crop: Millet, Sorghum & Organic & $\begin{array}{l}\text { C:11, S:7, G:10 } \\
\text { IPR } \\
\text { High grazing pressure }\end{array}$ & 30 \\
\hline Djougou & $\begin{array}{l}\text { Cultivated crops and fallow } \\
\text { Yam, tec, karite }\end{array}$ & Organic & $\begin{array}{l}\mathrm{C}: 8.5, \mathrm{~S}: 5, \mathrm{G}: 6 \\
\text { Low grazing pressure }\end{array}$ & 18 \\
\hline Lamto & $\begin{array}{l}\text { Pineapple, coffee, cacao } \\
\text { V Baoule shape }\end{array}$ & Synthetic & $\begin{array}{l}\text { C:7, S:8, G:6 } \\
\text { Low grazing pressure }\end{array}$ & 20 \\
\hline
\end{tabular}

Dry savanna ecosystems are characterized by a strong annual vegetation cycle, as stated by FAPAR (Fraction of Absorbed Photosynthetically Active Radiation) curves given for the Sahel region in Galy-Lacaux et al. (2009), and showing the level of vegetation photosynthetic activity, which signifies the amount, state and health of vegetation canopies. These curves show the strong seasonal cycle of the vegetation in the Sahel, with a small yearly average variability, whereas wet savanna ecosystems present perennial vegetation. These particular features involve different consumption and release of $\mathrm{N}$ in the soils, leading to less emissions to the atmosphere in more vegetated areas, whereas more $\mathrm{N}$ is lost to the atmosphere in dry savannas before the growing of the vegetation, at the beginning of the wet season.

NO emission from soil is also enhanced after fire occurence, as mentionned by Serça et al. (1998), NO fluxes are the result of the product of site and fire effect, (an example is shown in Table 7). Indeed, this process could be explained by the immediate impact of fire on nitrogen cycling, with an increase of the nitrification activity (Menaut et al., 1993). Furthermore, it has been shown that fire seldom decreases total soil $\mathrm{N}$ pools. $\mathrm{N}$ volatilization losses caused by frequent burning in savannas are often balanced by $\mathrm{N}$ inputs in nonassociative $\mathrm{N}$ fixation, or $\mathrm{N}$ deposition in rain (Coetsee et al., 2010).

Figure 1 gives the geographical location and the dominant ecosystem type of the IDAF stations.

\subsection{Emission fluxes}

Tropical savannas may be major sources of Nitrogen Oxides (NO) (Cardenas et al., 1994; Poth et al., 1995; Delmas et al., 1991; Serça et al., 1998). However, the vast majority of existing data have been collected in Central and South American ecosystems. In contrast, only few data exist on natural NO emissions from African ecosystem (Serça et al., 1994; Meixner et al., 1997; Scholes et al., 1997; Feig et al., 2008). Furthermore, in West Africa, biomass burning contributes to increase $\mathrm{N}$ compounds concentrations in the atmosphere, through NOx and $\mathrm{NH}_{3}$ emissions (Delmas et al., 1995). $\mathrm{NH}_{3}$ volatilization is also an important and largely unstudied N loss term (Schaeffer et al., 2003; Bouwman et al., 1997), contributing to $\mathrm{N}$ deposition in areas downwind of sources.

Each potential source of $\mathrm{N}$ compound emission to the atmosphere used in this study is detailed in this paragraph. Table 4 gives a synthesis of all the methods of calculation for emission and deposition fluxes used in this study. Table 5 gives brieve explanations on how uncertainties have been calculated for each flux. For more details on the whole calculation procedure, the reader is invited to refer to Delon et al. (2010).

\subsubsection{Biomass burning}

The global biomass burning inventories for $\mathrm{NO}_{\mathrm{x}}$ and $\mathrm{NH}_{3}$, use the L3JRC burnt area product based on the SPOT-VGT vegetation satellite and Global Land Cover (GLC) vegetation map, together with data on biomass densities and burning efficiencies (Liousse et al., 2010). Emission factors for gaseous species were chosen following Andreae and Merlet (2001). Monthly emissions are evaluated around each site in a $5^{\circ} / 5^{\circ}$ window. All the database was exploited here to derive interannual emissions from 2002 to 2007 . Note that the biomass density is not a dynamic parameter in the algorithm. The interannual variability of biomass burning is only determined 
Table 4. Methods and models used for the calculation of emission and deposition fluxes.

\begin{tabular}{lll}
\hline Flux & Method description & Model (or calculation) used \\
\hline Biogenic NO & SVAT Model & ISBA \\
Biomass burning fires & Satellites & SPOT-VGT vegetation satellite and Global Land Cover (GLC) vegetation map \\
Biofuel fires & Existing Database & Emission factors inventory for biofuels \\
Ammonia volatilization & Existing Database & Livestock population and N release from manure \\
Dry deposition Velocity & SVAT model & ISBA \\
Gas concentrations & In situ measurements & Passive samplers \\
Dry deposition flux & Inferential method & dry deposition velocity $\times$ concentration \\
Wet deposition flux & In situ measurements & Precipitation collector \\
\hline
\end{tabular}

Table 5. Uncertainties linked to the calculation of emission and deposition fluxes. $\mathrm{A}=$ Agoufou, $\mathrm{B}=\mathrm{Banizoumbou}, \mathrm{K}=\mathrm{Katibougou}$, $\mathrm{D}=$ Djougou, $\mathrm{L}=$ Lamto. $\mathrm{EF}=$ Emission Factor.

\begin{tabular}{|c|c|c|}
\hline Flux & Sources of Uncertainties & References \\
\hline Biogenic NO & $\begin{array}{l}\text { Non linear function on soil temperature and moisture } \\
\text { A: 3-42\%, B: 4-42\%, K: 7-68\%, D: 2-46\% L: 3-90\% }\end{array}$ & Delon et al. (2010) \\
\hline Biomass burning & $\begin{array}{l}\text { Burnt areas: } 20 \% \text {, Burning efficiency: } 25 \% \\
\text { Biomass dendity: } 30 \% \text {, Emission factor: } 31 \% \text {, Total: } 54 \%\end{array}$ & Liousse et al. (2010) \\
\hline Biofuel & $\begin{array}{l}\text { Wood and charcoal consumption: } 50 \% \text {, EF: } 31 \% \\
\text { Total: } 60 \%\end{array}$ & $\begin{array}{l}\text { Junker and Liousse (2008) } \\
\text { Assamoi and Liousse (2010) }\end{array}$ \\
\hline Ammonia volatilization & $\begin{array}{l}\text { Animal population: } 10 \%, \mathrm{~N} \text { release: } 50 \% \\
\text { Total: } 51 \%\end{array}$ & Bouwman et al. (1997), FAO \\
\hline Dry deposition Velocity & $\begin{array}{l}\text { Wind forcing, rugosity: } \mathrm{NO}_{2}: 13 \%, \mathrm{HNO}_{3}: 19 \%, \mathrm{NH}_{3}: 15 \% \\
\text { Chemical reactions: } \mathrm{NO}_{2}: 35 \% \\
\text { Monthly integration (missing cov) : } \mathrm{NO}_{2}: 20 \%, \mathrm{HNO}_{3} \text { and } \mathrm{NH}_{3}: 10 \%\end{array}$ & $\begin{array}{l}\text { Vila-Guerau and Duynkerke (1992) } \\
\text { Matt and Meyers (1993) }\end{array}$ \\
\hline Gas concentrations & $\begin{array}{l}\text { Covariance of duplicate samples: } \mathrm{NO}_{2}: 9.8 \% \\
\mathrm{HNO}_{3}: 20 \%, \mathrm{NH}_{3}: 14.3 \%\end{array}$ & Adon et al. (2010) \\
\hline Dry deposition flux & Total: $\mathrm{NO}_{2}: 70 \%, \mathrm{HNO}_{3}: 38 \%, \mathrm{NH}_{3}: 31 \%$ & \\
\hline Wet deposition flux & Rain gauge measurements: $10 \%$ for all species & Galy-Lacaux and Modi (1998) \\
\hline
\end{tabular}

by the variability of burned surfaces. The total uncertainty applied on $\mathrm{NH}_{3}$ and $\mathrm{NO}_{\mathrm{x}}$ fluxes is $54 \%$ (detail is given in Table 5).

Long range transport of biomass burning emission compounds from the southern hemisphere does not affect northern sites of dry savanna areas (Mari et al. (2008), Sauvage et al. (2007)). This is not the case for wet savanna sites that are situated further south $\left(9.7^{\circ} \mathrm{N}\right.$ for Djougou, and $6.1^{\circ} \mathrm{N}$ for Lamto), and that may be impacted by potential dry deposition of $\mathrm{N}$ compounds from biomass burning occuring in the southern hemisphere (Thouret et al., 2009) in June-JulyAugust (dry season of the southern hemisphere). Ammonium and nitrate loads in rains in the wet savanna of Lamto has been believed to be due to regional sources (animal waste and emissions by natural soils) as well as biomass burning and domestic fuelwood burning (Yoboué et al., 2005). Biomass burning influence from the southern hemisphere is indirectly taken into account in wet deposition fluxes.

\subsubsection{Domestic fires}

The rural population in Africa relies on wood and charcoal as the main fuels for domestic consumption (de Montalembert and Clement, 1983). In rural areas of Africa, and often among urban population also (Barnes et al., 2001), much of the biofuel is used for cooking all along the year without any seasonal pattern in contrast to other types of biomass burning which tend to follow seasonal patterns (Duncan et al., 2003). The source of $\mathrm{NO}_{\mathrm{x}}$ from biofuel and field burning is about $10 \%$ of the source from fossil fuel combustion (Yevich and Logan, 2003), with strong variations at the regional scale.

Emissions of $\mathrm{NO}_{\mathrm{x}}$ and $\mathrm{NH}_{3}$ by domestic fires in dry and wet savannas have been evaluated at the yearly scale considering the methodology developed in Junker and Liousse (2008) and Delon et al. (2010). Yearly emissions (typical for 2003) are evaluated around each site in a $5^{\circ} / 5^{\circ}$ window. Uncertainties are mainly linked to wood and charcoal consumption estimates (50\%, Assamoi and Liousse, 2010) and 
emission factors (31\%, Andreae and Merlet (2001). The total uncertainty applied to domestic fires is $60 \%$ for both compounds.

\subsubsection{Biogenic Nitrogen Oxide (NO) from soils}

Nitric oxide is a gaseous intermediate of both nitrification and denitrification processes. In sites that receive pulsed precipitation events or extended dry periods, wetting of a previously dry soil often results in a large flux of NO (Davidson et al., 1991; Davidson et al., 1993; Scholes et al., 1997; Martin et al.,, 1998; Hartley and Schlesinger, 2000).

Biogenic NO fluxes are simulated with the model ISBA (Interaction Surface Biosphere Atmosphere, Noilhan and Mahfouf (1996)), coupled with a Neural Network derived emission module (Delon et al. (2007), Delon et al. (2008), Delon et al. (2010)). Emissions depend on surface WFPS (Water Filled Pore Space), soil temperature at two depths (surface and $20-30 \mathrm{~cm}$ ), wind speed, $\mathrm{pH}$, sand percentage, and fertilization rate. Soil moisture has the prominent influence in dry savanna ecosystems, because of strong pulses of emission at the beginning at the wet season, when the first rains fall on very dry soils (Jaeglé et al. (2004), Stewart et al. (2008), Delon et al. (2008)). In wet savanna, this phenomenon is reduced, due to higher soil moisture content even during the dry season. The uncertainty of the biogenic NO flux from soil depends strongly on the soil humidity, and hence on the month of the year. It is therefore different from one site to the other, and the highest uncertainties are found during the driest months (when the emissions are the lowest). In annual mean, the uncertainty is $17 \%$ in Agoufou, $23 \%$ in Banizoumbou, $21 \%$ in Katibougou, $18 \%$ in Djougou, and $50 \%$ in Lamto. Actually, this uncertainty is invevitably underestimated, because it is based on simulated soil moisture and temperature, which own uncertainties increase the resultant uncertainty on fluxes. Furthermore, $\mathrm{pH}$, sand percentages, and fertilisation rates are taken from global or hand made databases, which further increases the flux uncertainty. The total uncertainty is hard to quantify. Therefore, a $20 \%$ annual mean uncertainty for all sites will be applied as a lowest estimate, except in Lamto, where a $50 \%$ uncertainty is applied.

Meteorological conditions needed to run the ISBA model are provided by the forcing, derived from satellite data, and developed in ALMIP (AMMA Land surface Model Intercomparison Project), described in Boone et al. (2009).

\subsection{4 $\mathrm{NH}_{3}$ volatilization}

Large pulse of $\mathrm{NO}$ after wetting of a previously dry soil coincides with an increase in extractable soil $\mathrm{NH}_{4}^{+}$and high rates of gross $\mathrm{N}$ mineralization and nitrification (Davidson et al., 1993). Similar to NO production from nitrification, rates of $\mathrm{NH}_{3}$ volatilization are sensitive to soil conditions that influence $\mathrm{NH}_{4}^{+}$concentrations and turnover in the soil (Barger et al., 2005). An illustration of this process is given in Adon et al. (2010), who show that the seasonal cycle of ammonia and nitric dioxide are strongly correlated. Subsequently, NO and $\mathrm{NH}_{3}$ emissions are linked and both sensitive to constraints on microbial activity (McCalley et al., 2008). For the remote sites of the IDAF network, neither industrial nitrogen sources nor nitrogenous emissions from synthetic fertilization need to be considered (except in Lamto), due to the remoteness of sites from large cities. Bouwman et al. (1997) have stated that synthetic fertilization in West Africa is less than $0.5 \mathrm{kgNha}^{-1} \mathrm{yr}^{-1}$, whereas organic fertilization from domestic animal can be much larger, as described below. The $\mathrm{NH}_{3}$ flux released to the atmosphere by volatilization is calculated from the $\mathrm{N}$ input by organic fertilization. This $\mathrm{N}$ input is the product of the $\mathrm{N}$ release by livestock, in $\mathrm{kgNanimal}^{-1} \mathrm{yr}^{-1}$, adapted from Mosier et al. (1998) and Schlecht and Hiernaux (2004), by the Animal population in each region of each country (Food and Agriculture Organization, FAO, Global Livestock Production and Health Atlas GLiPHA (2009, http: //kids.fao.org/glipha/). A total N input of $23 \mathrm{kgNha}^{-1} \mathrm{yr}^{-1}$ in Agoufou (Mali), $25 \mathrm{kgNha}^{-1} \mathrm{yr}^{-1}$ in Banizoumbou (Niger), $11 \mathrm{kgNha}^{-1} \mathrm{yr}^{-1}$ in Katibougou (Mali), $8 \mathrm{kgNha}^{-1} \mathrm{yr}^{-1}$ in Djougou (Benin) and $8 \mathrm{kgNha}^{-1} \mathrm{yr}^{-1}$ in Lamto (Ivory Coast) has been calculated.

$30 \%$ of this $\mathrm{N}$ input is released to the atmosphere by $\mathrm{NH}_{3}$ volatilization, the rest is assimilated in soils and used as fertilization rate for the biogenic $\mathrm{NO}$ emission in ISBA, described above. This rate of $30 \%$ has been deduced from other studies: Bouwman et al. (1997), Bouwman and Van Der Hoek (1997) and Bouwman et al. (2002) have found that the fraction of the $\mathrm{N}$ excretion that is lost as $\mathrm{NH}_{3}$ ranges from 10 to $36 \%$, depending on animal-waste management and animal category. As a consequence, the $\mathrm{N}$ released by volatilization in Agoufou is $7.2 \mathrm{kgNha}^{-1} \mathrm{yr}^{-1}, 7.7 \mathrm{kgNha}^{-1} \mathrm{yr}^{-1}$ in Banizoumbou, $3.4 \mathrm{kgNha}^{-1} \mathrm{yr}^{-1}$ in Katibougou, $2.5 \mathrm{kgNha}^{-1} \mathrm{yr}^{-1}$ in Djougou and $2.3 \mathrm{kgNha}^{-1} \mathrm{yr}^{-1}$ in Lamto.

In the present study, an intra annual variation of $\mathrm{NH}_{3}$ volatilization has been added, with higher emissions during the wet season. The increase in soil moisture at the beginning of the wet season is correlated to the increase of $\mathrm{NO}$ and $\mathrm{NH}_{3}$ concentrations in the dry savanna sites (Adon et al., 2010). Furthermore, the excreta quantity is not constant throughout the year, and presents a maximum at the end of the wet season, both in Agoufou and Banizoumbou (Hiernaux et al. (1998), Hiernaux and Turner (2002), Schlecht and Hiernaux (2004)), because animals have been better fed during the wet season. The excreta quality is also increased during the wet season, but too few data on the subject are available to be included in our study. Due to a lack of equivalent studies in Katibougou, Djougou and Lamto, we have supposed that the processes were similar than in Agoufou and Banizoumbou, but with a smoother intensity because the available vegetation for grazing is more important in Katibougou, Djougou and Lamto than in Agoufou and Banizoumbou, due to their 
latitudinal position. The quantity of $\mathrm{N}$ released from animal excreta will therefore be maximum in October and November. The combination of these two processes (increase of soil moisture at the beginning of the wet season and increase of excreta quantity at the end of the wet season) gives a monthly evolution of the $\mathrm{NH}_{3}$ volatilization, showing 2 maxima in June and October.

\subsection{Deposition fluxes}

\subsubsection{Dry deposition fluxes}

The dry deposition flux (molec $\mathrm{cm}^{-2} \mathrm{~s}^{-1}$ ) is the product of the measured concentration $\left(\right.$ molec $\mathrm{cm}^{-3}$ ) by the deposition velocity $\left(\mathrm{cms}^{-1}\right)$. The deposition velocity is simulated in the ISBA surface model according to Wesely (1989). Cuticle and soil resistances for each site are based on the parameterization developed in Zhang et al. (2003) (i.e. soil resistances depend on the type of soil and vegetation found on site). The meteorological forcing used for these simulations is the same as the one used for the biogenic NO emission fluxes calculation (ALMIP forcing). However, the forcing in ALMIP is available at $10 \mathrm{~m}$, whereas the concentrations of gases are measured at $1.5 \mathrm{~m}$. A logarithmic decrease of the wind forcing from 10 to $1.5 \mathrm{~m}$, depending on the rugosity of the site, has been applied, to calculate deposition velocities at $1.5 \mathrm{~m}$.

The concentrations are measured at each site by passive samplers. The sampling procedure and chemical analysis of samples, as well as the validation method, have been widely detailed in Adon et al. (2010). Furthermore, Adon et al. (2010) present the evolution of $\mathrm{NO}_{2}, \mathrm{NH}_{3}$ and $\mathrm{HNO}_{3}$ concentrations along the period 1998-2007 for each IDAF station.

The total uncertainty applied to the fluxes is linked to the concentration measurements, the deposition velocity, and to terms associated to the turbulence in the atmosphere and assumptions made to obtain monthly means of deposition velocities. The total rate of uncertainty applied for deposition fluxes is $70 \%$ for $\mathrm{NO}_{2}, 31 \%$ for $\mathrm{NH}_{3}$ and $38 \%$ for $\mathrm{HNO}_{3}$ (Delon et al., 2010), synthesized in Table 5.

\subsubsection{Wet deposition fluxes}

An automatic precipitation collector, specially designed for the IDAF network was located in the five IDAF sites (GalyLacaux et al., 2009). The automatic instrument collects precipitation with a high degree of cleanliness in a single-use polyethylene bag, avoiding aerosol deposit before the onset of the rain. The surface of rain collection is $225 \mathrm{~cm}^{2}$. After each precipitation event, $50 \mathrm{~cm}^{2}$ of the collected precipitation is sampled in Greiner tubes. The preservation of the rainwater samples is an important problem because of microbial degradation which can modify the chemical composition of rainwater. All samples were stored in a deep freeze environment from collection to analysis.
The wet deposition flux is the product of the ammonium and nitrate concentrations in rain (annual Volume Weighted Mean VWM) by the annual rainfall. Dissolved Organic Nitrate (DON) is not measured, which introduces an underestimation of the budget, in a proportion that could reach $20 \%$ of the wet deposition flux (Whitall et al., 2002; Hill et al., 2005, Mace et al., 2003).

\section{Results and discussion}

Monthly means (from 3-hourly values from ISBA simulations) of deposition velocities for $\mathrm{NO}_{2}, \mathrm{HNO}_{3}$ and $\mathrm{NH}_{3}$ have been calculated in order to reproduce the seasonal cycle of the deposition process at each site. Monthly mean values of deposition velocities for $\mathrm{HNO}_{3}$ range from 0.40 to $1.00 \mathrm{cms}^{-1}$ (average: $0.63 \pm 0.13 \mathrm{~cm} . \mathrm{s}^{-1}$ ) in Agoufou, 0.42 to $1.11 \mathrm{cms}^{-1}$ (average: $0.72 \pm 0.15 \mathrm{cms}^{-1}$ ) in Banizoumbou, 0.49 to $1.13 \mathrm{cms}^{-1}$ (average: $0.73 \pm 0.13 \mathrm{cms}^{-1}$ ) in Katibougou, 0.43 to $0.91 \mathrm{cms}^{-1}$ (average: $0.65 \pm 0.11 \mathrm{cms}^{-1}$ ) in Djougou and 0.52 to $0.85 \mathrm{cms}^{-1}$ (average: $0.69 \pm 0.08 \mathrm{cms}^{-1}$ ) in Lamto. Maximum values are close to mean values calculated in European ecosystems over short vegetation (such as grasslands or peats) by Flechard et al. (2011), showing $\mathrm{HNO}_{3} \mathrm{Vd}$ in the range of 1.0 to $1.2 \mathrm{cms}^{-1}$. The types of vegetation and soil are completely different between the tropical sites considered in this study and the european sites of Flechard et al. (2011) study, and maximum values are found during the wet season, when the vegetation cover and the soil moisture are at their maximum, whereas soil moisture in european sites is less subject to such drastic seasonal changes. However, the annual means remain 2 to 3 times lower than deposition velocities calculated by Zhang et al. (2003) for deserts and short grass ecosystems. This discrepancy is mainly due to the fact that deposition velocities in Zhang et al. (2003) are calculated at $20 \mathrm{~m}$ above ground, whereas deposition velocities in the present study are calculated at $1.5 \mathrm{~m}$. In that case, direct comparison of deposition velocities is not adequate because of large differences in the wind speeds between the two heights. $\mathrm{NO}_{2}$ deposition velocities range from 0.13 to $0.35 \mathrm{cms}^{-1}$ (average: $0.20 \pm 0.06 \mathrm{cms}^{-1}$ ) in Agoufou, 0.14 to $0.39 \mathrm{cms}^{-1}$ (average: $0.23 \pm 0.07 \mathrm{cms}^{-1}$ ) in Banizoumbou, 0.14 to $0.43 \mathrm{cmvs}^{-1}$ (average: $0.23 \pm 0.08 \mathrm{cms}^{-1}$ ) in Katibougou, 0.18 to $0.46 \mathrm{cms}^{-1}$ (average: $0.31 \pm 0.08 \mathrm{cms}^{-1}$ ) in Djougou and 0.21 to $0.46 \mathrm{cms}^{-1}$ (average: $0.35 \pm 0.06 \mathrm{cms}^{-1}$ ) in Lamto. $\mathrm{NH}_{3}$ deposition velocities range from 0.14 to $0.41 \mathrm{cms}^{-1}$ (average: $0.23 \pm 0.07 \mathrm{cms}^{-1}$ ) in Agoufou, 0.16 to $0.49 \mathrm{cms}^{-1}$ (average: $0.27 \pm 0.10 \mathrm{cms}^{-1}$ ) in Banizoumbou, 0.16 to $0.53 \mathrm{cms}^{-1}$ (average: $\left.0.28 \pm 0.10 \mathrm{cms}^{-1}\right)$ in Katibougou, 0.22 to $0.52 \mathrm{cms}^{-1}$ (average: $0.37 \pm 0.10 \mathrm{cms}^{-1}$ ) in Djougou, and 0.26 to $0.54 \mathrm{cms}^{-1}$ (average: $0.42 \pm 0.07 \mathrm{cms}^{-1}$ ) in Lamto. 
Although bi directional air surface exchange of $\mathrm{NH}_{3}$ has been frequently observed over a variety of land surfaces, due to a lack of data, the compensation point concept is not applied in this study for the calculation of $\mathrm{NH}_{3}$ dry deposition flux. Indeed, Zhang et al. (2010) have stated that semi natural vegetation are generally not exposed to large amounts of $\mathrm{N}$ and therefore tend to be a sink for $\mathrm{NH}_{3}$ rather than a source, with compensation point values close to zero. In our study, deposition and emission fluxes of $\mathrm{NH}_{3}$ are evaluated separately, giving at the end the net flux of $\mathrm{NH}_{3}$ as it should be done using the compensation point concept. However, $\mathrm{NH}_{3}$ concentrations can be large in savanna areas, as shown in Adon et al. (2010), and non evaluating the compensation point effect will inevitably involve a supplementary source of uncertainty on $\mathrm{NH}_{3}$ net flux, rather difficult to assess.

\subsection{Results}

Figure 2 and Fig. 3 show the detail of nitrogen oxidized and reduced compounds emission and dry deposition fluxes, at the 5 IDAF stations. The results are presented along a pluviometry gradient, from Agoufou, the northernmost position to Lamto, the southernmost site.

\subsubsection{Ammonia release}

Oxidized (Fig. 2a-e) and reduced (Fig. 3a-e) N compounds deposition and emission fluxes in monthly means are presented separately to better understand the sources influence. In Fig. $3 \mathrm{NH}_{3}$ concentrations are also presented alongside the simulated fluxes.

In dry savanna sites (Agoufou, Banizoumbou and Katibougou), Fig. 2 and Fig. 3 shows that a first maximum of emissions is found at the beginning of the rain season (both for reduced and oxidised compounds), due to the starting up of the microbial activity consecutive to higher soil moisture. A rebound is observed in $\mathrm{NH}_{3}$ concentrations and dry deposition fluxes in October, due to the increase of $\mathrm{N}$ content in cattle dung at the end of the wet season. A third increase (almost visible in Djougou and Lamto) is observed during the dry season, because of biomass burning emissions (except in Agoufou, where regional biomass burning sources do not affect the site). These rebounds are smoothed on the flux signal (compared to the concentrations) because deposition velocities decrease sharply at the end of the wet season (september in dry savanna) and reach their lowest value during the dry season. $\mathrm{NH}_{3}$ volatilization and further deposition show a strong seasonnal variation in dry savanna areas, because rates of $\mathrm{NH}_{3}$ volatilization are sensitive to soil moisture conditions, as explained above. The interannual variability of $\mathrm{NH}_{3}$ volatilization cannot be discussed here, because data are given for a single year and reproduced each year in the same way. In wet savannas (Djougou and Lamto), the ammonia release is mostly due to biomass burning emissions, discussed below. Thanks to a higher soil water content all along
Table 6. Emission fluxes in annual mean, in $\mathrm{kgNha}^{-1} \mathrm{yr}^{-1}$ for dry and wet savanna ecosystems. $\mathrm{BB}=$ Biomass Burning, $\mathrm{BF}=$ Biofuel.

\begin{tabular}{lll}
\hline Emission flux & Dry savanna & Wet savanna \\
\hline Biogenic NO & $1.39 \pm 0.28$ & $2.12 \pm 0.20$ \\
$\mathrm{NO}_{\mathrm{x}} \mathrm{BB}$ & $0.61 \pm 0.52$ & $2.20 \pm 0.40$ \\
Volatilization & $6.09 \pm 2.31$ & $2.40 \pm 0.09$ \\
$\mathrm{NH}_{3} \mathrm{BB}$ & $0.40 \pm 0.35$ & $1.91 \pm 0.56$ \\
$\mathrm{NO}_{\mathrm{x}}+\mathrm{NH}_{3} \mathrm{BB}$ & $1.02 \pm 0.87$ & $4.11 \pm 0.96$ \\
$\mathrm{NO}_{\mathrm{x}}+\mathrm{NH}_{3} \mathrm{BF}$ & $0.29 \pm 0.20$ & $0.97 \pm 0.02$ \\
\hline
\end{tabular}

the year, seasonal variations in $\mathrm{NH}_{3}$ volatilization and further deposition are less marked. $\mathrm{NH}_{3}$ concentrations and deposition fluxes have a close evolution, highlighting the idea that local sources variations have a stronger impact on fluxes than inter annual meteorological variations (meteorological variations have an impact on deposition velocities, and therefore on deposition fluxes, which would not, in that case, follow the concentration evolution).

\subsubsection{Biogenic emissions from soils}

In the five sites studied in this work, biogenic NO emission fluxes are less important in wet savanna only if the wet seasonal mean is calculated: wet seasonal means give $3.2 \pm 0.6 \mathrm{kgNha}^{-1} \mathrm{yr}^{-1}$ in dry savanna sites, and $2.6 \pm 0.7$ $\mathrm{kgNha}^{-1} \mathrm{yr}^{-1}$ in wet savanna sites. No pulse effect occurs in wet savannas because of higher mean soil water content. Dry season emissions are nearly 0 in dry savanna sites, whereas they keep being significant in wet savanna sites. Consequently, the annual mean for dry savanna sites is only $1.39 \pm 0.28$ whereas it is $2.12 \pm 0.20$ in wet savannas (Table 6).

Very few measurements have been done in these regions, and some have not been published. During the AMMA program, several field campaigns have been performed in Agoufou (in 2004) and Djougou (in 2005 and 2006), giving an order of magnitude for biogenic NO fluxes at different seasons. These results are presented in Table 7, together with literature data from Lamto and Banizoumbou. Measurements performed in dry savanna (Agoufou and Banizoumbou) give higher averages than those from wet savannas (Djougou and Lamto). Dry savanna modelled fluxes are in accordance with measurements, whereas in wet savanna, modelled fluxes overestimate measurements.

While different in magnitude, several processes are common to dry and wet savanna ecosystems: If rain increases during the wet season, the biogenic NO emission increases, as well as the Oxidized $\mathrm{N}$ dry deposition fluxes (Fig. 2a-e). The difference between wet and dry savanna ecosystem in their capacity to release biogenic NO from soils may find some explaination in microbial processes, and in the dominant vegetation type, different in wet and dry savannas, as 

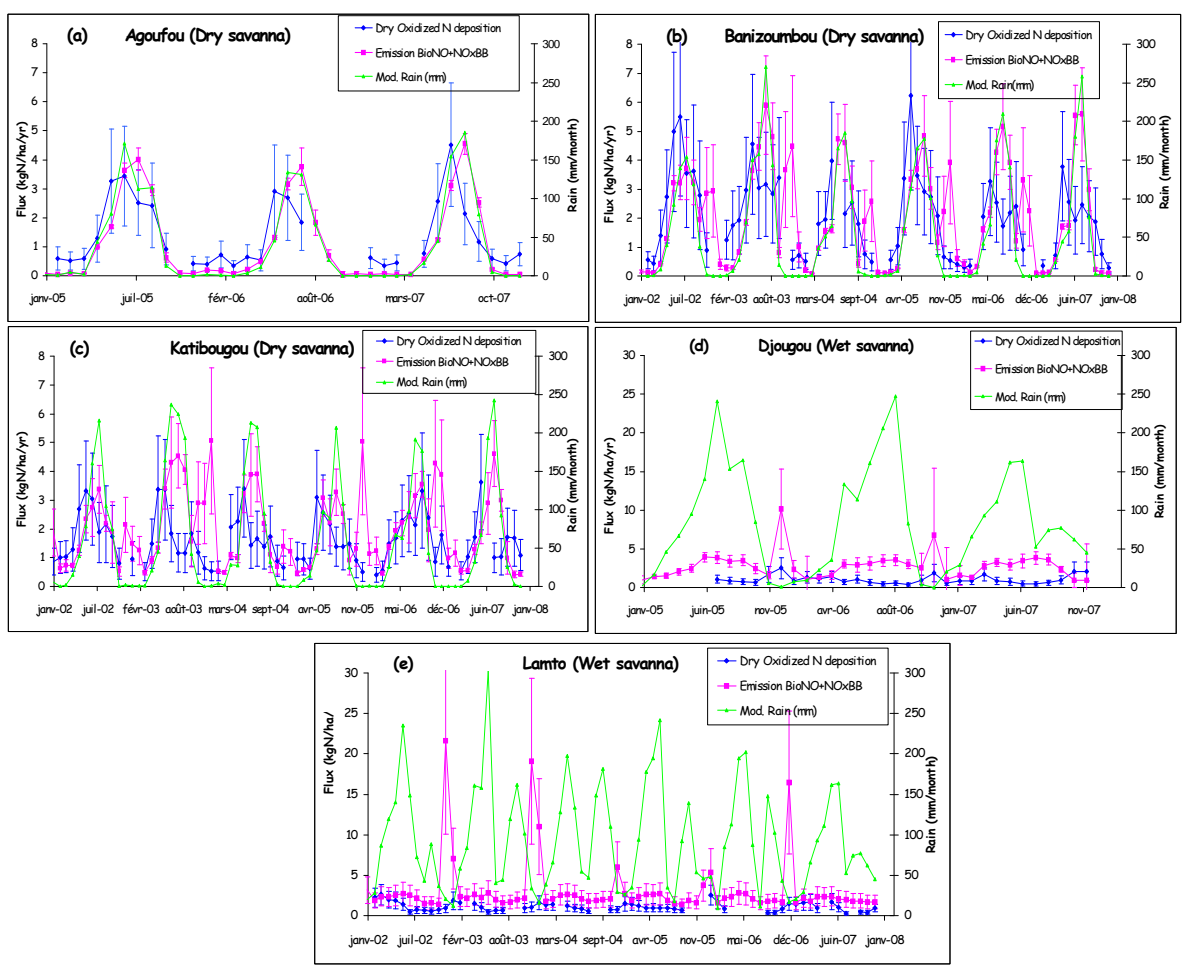

Fig. 2. Interannual evolution of oxidised $\mathrm{N}$ fluxes (Biogenic $\mathrm{NO}$ from soils $+\mathrm{NO}_{\mathrm{x}}$ emission from biomass burning in pink, $\mathrm{NO}_{2}+\mathrm{HNO}_{3}$ dry deposition in blue, rainfall in green) in Agoufou (a), Banizoumbou (b), Katibougou (c), Djougou (d), and Lamto (e).
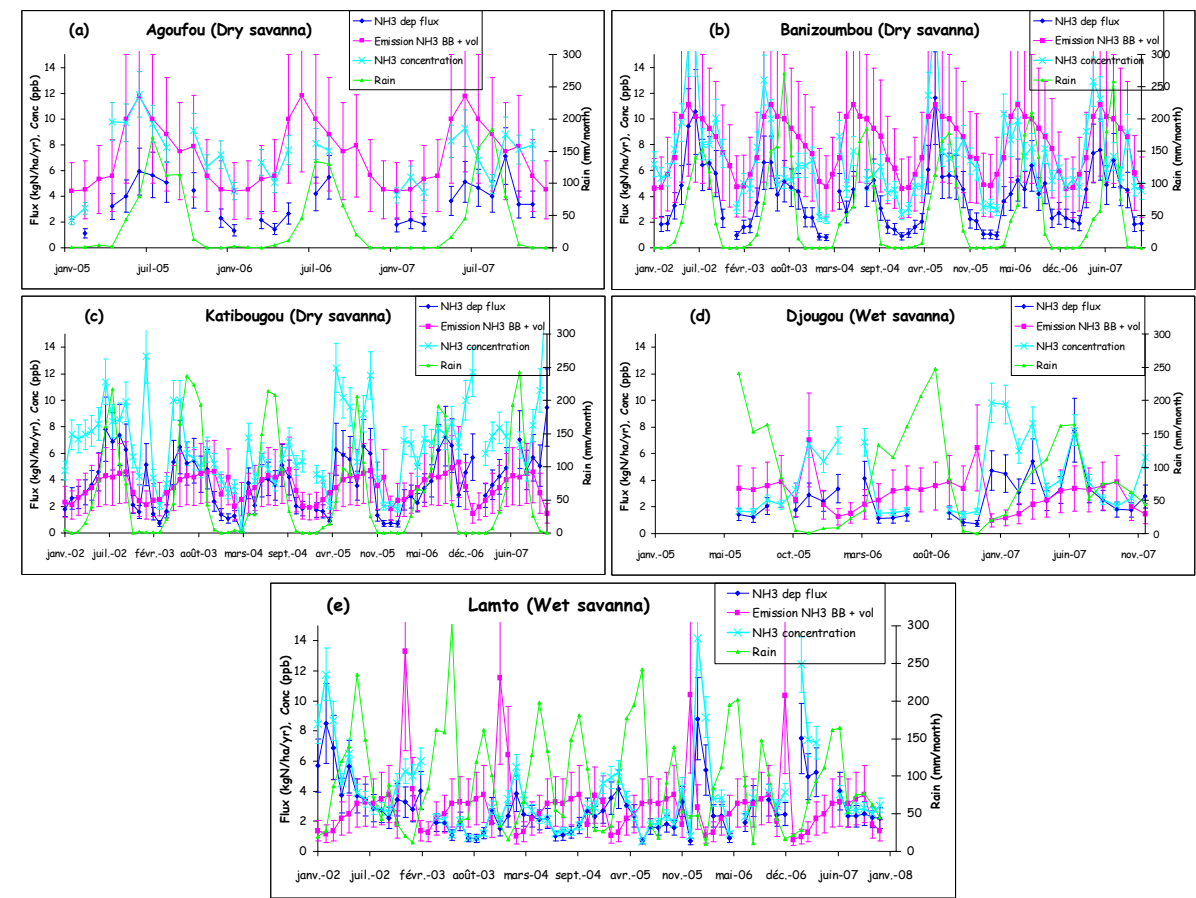

Fig. 3. Interannual evolution of reduced $\mathrm{N}$ fluxes $\left(\mathrm{NH}_{3}\right.$ volatilization $+\mathrm{NH}_{3}$ emission from biomass burning in pink, $\mathrm{NH}_{3}$ dry deposition in blue, $\mathrm{NH}_{3}$ concentration in light blue, rainfall in green), in Agoufou (a), Banizoumbou (b), Katibougou (c), Djougou (d), and Lamto (e). 
stated in Table 2: Hyparrhenia, dominant in wet savannas, inhibits nitrification processes and therefore biogenic NO fluxes, which could explain the lower biogenic $\mathrm{NO}$ emissions during the wet season in Djougou and Lamto, compared to dry savanna emissions.

Surface soils in arid and semi arid ecosystems often experience large seasonal fluctuations in moisture content, and the mineralization pulse associated with soil drying/rewetting has the potential to significantly impact $\mathrm{N}$ release, whereas comparatively in soils maintained at equivalent mean soil moisture, the $\mathrm{N}$ turnover is decreased (Millet et al., 2004). The results found in this work confirm these processes if we focus on wet seasonal means.

\subsubsection{Biomass burning}

If rain is sufficient, the vegetation will grow during the wet season, and $\mathrm{NO}_{\mathrm{x}}$ and $\mathrm{NH}_{3}$ emission from biomass burning should increase during the following dry season.

In dry savanna ecosystems, $\mathrm{NO}_{\mathrm{x}}$ emissions from biomass burning is twice lower than NO biogenic emission from soils. Indeed, the significant pulse effect occuring at the beginning of the wet season allows high biogenic emissions, whereas in contrast low vegetation density is available in the Sahel region (almost null in Agoufou where no biomass burning emission is measured) leading to a low amount of burned biomass. Biogenic NO emissions from soils and $\mathrm{NO}_{\mathrm{x}}$ emissions from biomass burning in annual means represent respectively $1.39 \pm 0.28 \mathrm{kgNha}^{-1} \mathrm{yr}^{-1}$ and $0.61 \pm 0.52 \mathrm{kgNha}^{-1} \mathrm{yr}^{-1}$ in dry savanna ecosystems (Table $6)$.

Some particular features are observed in wet savanna ecosystems: the vegetation density is more important in Djougou and Lamto, which leads to $\mathrm{NO}_{\mathrm{x}}$ biomass burning emission equivalent to the $\mathrm{NO}$ biogenic emission from soils $\left(2.20 \pm 0.40 \mathrm{kgNha}^{-1} \mathrm{yr}^{-1}\right.$ and $2.12 \pm 0.20 \mathrm{kgNha}^{-1} \mathrm{yr}^{-1}$ respectively in annual means).

In dry savannas, the $\mathrm{NH}_{3}$ biomass burning emission signal in Fig. 3a-c (around november-december, detected through the increase in the $\mathrm{NH}_{3}$ concentration, is flooded by the volatilization signal (up to $11 \mathrm{kgNha}^{-1} \mathrm{yr}^{-1}$ in Agoufou and Banizoumbou, and $5 \mathrm{kgNha}^{-1} \mathrm{yr}^{-1}$ in Katibougou). The annual mean for volatilization is $6.09 \pm 2.31 \mathrm{kgNha}^{-1} \mathrm{yr}^{-1}$ in dry savanna, whereas the $\mathrm{NH}_{3}$ biomass burning emission is $0.40 \pm 0.35 \mathrm{kgNha}^{-1} \mathrm{yr}^{-1}$.

On the contrary, wet savanna ecosystems present a higher biomass burning emission signal of $\mathrm{NH}_{3}$ (Fig. 3d-e), which can reach $12 \mathrm{kgNha}^{-1} \mathrm{yr}^{-1}$ in Lamto and $6 \mathrm{kgNha}^{-1} \mathrm{yr}^{-1}$ in Djougou as maximum values, and gives an annual mean of $1.91 \pm 0.56 \mathrm{kgNha}^{-1} \mathrm{yr}^{-1}$, whereas volatilization reaches $4 \mathrm{kgNha}^{-1} \mathrm{yr}^{-1}$ as a maximum value in both sites $\left(2.40 \pm 0.09 \mathrm{kgNha}^{-1} \mathrm{yr}^{-1}\right.$ in annual mean). Total N emission from biomass burning in annual mean $\left(\mathrm{NO}_{\mathrm{x}}+\mathrm{NH}_{3}\right)$, is $1.02 \pm 0.87 \mathrm{kgNha}^{-1} \mathrm{yr}^{-1}$ in dry savanna ecosystems, and
$4.11 \pm 0.96 \mathrm{kgNha}^{-1} \mathrm{yr}^{-1}$ in wet savannas, directly linked to the quantity of biomass burned.

Domestic fires emissions do not present any interannual variability and annual means are $0.29 \pm 0.20 \mathrm{kgNha}^{-1} \mathrm{yr}^{-1}$ in dry savanna, and $0.97 \pm 0.02 \mathrm{kgNha}^{-1} \mathrm{yr}^{-1}$ in wet savanna, which represents respectively $3 \%$ and $10 \%$ of the total emission budget.

All annual means emission fluxes are reported in Table 6.

\subsection{Discussion}

\subsubsection{Variability of emission and deposition fluxes}

Africa leads all other continents in annual fire emissions but with relatively small interannual variability (van der Werf et al. (2006), Liousse et al. (2010)) at the continental scale. However, in our results we consider a regional scale ( $5^{\circ}$ around each local site), and a smaller time scale (7 years) than a climatic one (50 years considered in van der Werf et al. (2006) study). The availability of biomass (and consequently the quantity of resulting emissions by biomass burning) seems to be driven by the amount of rainfall during the wet season before. Indeed, a lagged correlation between monthly rainfall and monthly emission from biomass burning $\mathrm{N}$ compounds has been calculated, giving a 4 months lagged correlation rate of 0.7 in Banizoumbou, 0.6 in Katibougou and 0.6 in Djougou. In Lamto, the lagged correlation is 0.5 after 6 months. The lag is longer in Lamto, probably because of the longer duration of the rain season, and the correlation slightly lower because of the occurence of the second short wet season (around the month of October), not connected to a second burning season.

Interannual variability in soil water stress tends not to be highest in places that have the largest interannual variability in precipitation but rather at intermediate values (like in Soudano-Sahelian regions where Katibougou is situated), as water ceases to be a limiting factor with increasing rainfall despite continued increase in rainfall variability (Williams et al. (2008), the study focusing on the 1982-2003 period over the African continent). Low vegetation density and humidity stress may probably dampen the ecophysiological sensitivity to rainfall variability. Williams et al. (2008) have shown that Lamto and Djougou sites are situated in regions presenting a higher interannual variability in rainfall than in Sahelian regions, but with low impact on the interannual variability of soil water stress and vegetation cover.

At a more local scale, Mougin et al. (2009) have illustrated the fact that in the Gourma region (Mali) where Agoufou is situated, most of the inter-annual variation in annual herbaceous production result from inter-annual variation in the soil moisture regime driven by rainfall volume and distribution. Biogenic NO emissions are highly sentitive to soil water content (directly influenced by rainfall amount), which is somewhat different from soil water stress, i.e.: the soil water content gives the information on the water available for emission 
Table 7. Mean NO biogenic fluxes from unpublished data and from literature.

\begin{tabular}{llll}
\hline Site & NO flux $\left(\mathrm{kgNha}^{-1} \mathrm{yr}^{-1}\right)$ & Period of meas. & Reference \\
\hline Lamto & $0.17 \pm 0.07$ & Wet season, 1992 & Leroux at al. (1995) \\
Lamto & $0.41 \pm 0.12$ & Wet season, 1992 & Leroux at al. (1995) \\
Lamto & $0.12 \pm 0.04$ & Wet season, 1992 & Leroux at al. (1995) \\
Lamto & $0.09 \pm 0.02$ & Wet season, 1992 & Leroux at al. (1995) \\
Banizoumbou & $1.92 \pm 0.83$ & Wet season, 1992 & Leroux at al. (1995) \\
Lamto & $0.03 \pm 0.01$ & Dry season, before fire, 1992 & Serça et al. (1998) \\
Lamto & $0.20 \pm 0.10$ & Dry season, after fire, 1992 & Serça et al. (1998) \\
Agoufou & $2.58 \pm 3.86$ & Wet season, 2004 & Delon et al. (2007) \\
Agoufou & $0.81 \pm 0.51$ & Wet season, 2005 & Unpublished \\
Djougou & $0.43 \pm 1.34$ & Wet season, 2005 & Unpublished \\
Djougou & $0.62 \pm 0.42$ & Dry season, 2006 & Unpublished \\
\hline
\end{tabular}

processes, whereas soil water stress gives an information on a threshold under which microbes do not activate $\mathrm{N}$ production. Biogenic NO emissions decrease/increase if rainfall decreases/increases.

In our results, no significant common tendency appears between interannual variability in rainfall intensity and interannual variability in deposition fluxes quantity. Fig. 4 shows the evolution of total dry deposition fluxes $\left(\mathrm{NO}_{2}+\mathrm{HNO}_{3}+\mathrm{NH}_{3}\right)$ in $\mathrm{kgNha}^{-1} \mathrm{yr}^{-1}$ for dry and wet savannas, together with local rain measurements (in mmmonth ${ }^{-1}$ ). In dry savanna, the correlation between rainfall and total deposition is quite low but remains significant (0.51 at Agoufou, 0.33 at Banizoumbou and 0.34 at Katibougou), but does not allow to conclude on a possible intensity effect: i.e. the occurence of rain and deposition are linked, but if the magnitude of precipitations increases, it does not necessarily involve an increase of the intensity of deposition fluxes. Indeed, as explained before, deposition depends on emission processes, enhanced by rainfall events. The change in rainfall intensity from one year to another does not lead to a direct change in deposition flux intensity.

In wet savanna, correlation between rainfall and deposition fluxes is close to 0 , confirming the analysis that processes are less linked to the quantity of rainfall than in dry savanna. Once again, the interannual variability in rainfall quantity does not involve a direct response of emission and deposition processes. No interannual variability has been introduced for the volatilization of $\mathrm{NH}_{3}$ and for the emission of $\mathrm{NO}_{\mathrm{x}}$ and $\mathrm{NH}_{3}$ by domestic fires (data are given for a single year), which is probably the main reason for not being able to isolate common tendencies between rainfall quantity and $\mathrm{N}$ emission/deposition amounts. Furthermore, the short period of study (7 years) does not help the interpretation.

The variability in rainfall amount from year to year, induced by the WAM complex system, does not explain the interannual variability of wet deposition in one single ecosystem. As mentioned above, rainfall variation from year to year does not exceed $15 \%$ in the period 2002-2007, whereas wet deposition variation exceeds this rate in all stations. The complexity and retroactions between emission and deposition contributions prevents from finding an easy and direct link from rainfall to wet deposition. As detailed in GalyLacaux and Modi (1998), Galy-Lacaux et al. (2009) and Yoboué et al. (2005), wet deposition annual variations are mainly related to the combination of the natural rainfall and emissions sources variability. If the annual rainfall in each ecosystem does not explain variability in wet deposition, it should be interesting to study the distribution of the rain in each year during each rain season, to have a better understanding of wet depostition distribution. But this is beyond the scope of this study.

\subsubsection{Comparison between wet and dry savannas}

Figure 5a-b presents annual means of emission and deposition contributions for the years 2002 to 2007 in Banizoumbou, Katibougou and Lamto, and for the years 2005 to 2007 for Agoufou and Djougou. Error bars give the order of magnitude of the interannual variability for each component of the budget. As mentionned above, interannual variability is not specified for $\mathrm{NH}_{3}$ volatilization and for $\mathrm{NH}_{3}$ and $\mathrm{NO}_{\mathrm{x}}$ emission by domestic fires (biofuel), because for these parameters, data are given for a single year. However, it could be useful to recall that uncertainty is $50 \%$ for $\mathrm{NH}_{3}$ volatilization, and $60 \%$ for biofuel emission.

In Fig. 5a, significant differences appear between sites: Sahelian sites (Agoufou and Banizoumbou) present the highest values of $\mathrm{NH}_{3}$ volatilization, consequence of highly developed pastoralism in this region. Katibougou is located further south, and the number of cattle heads $\mathrm{km}^{-2}$ is less important (respectively 24, 22 and 11 cattle heads $\mathrm{km}^{-2}$ in Banizoumbou, Agoufou and Katibougou), leading to lower values of $\mathrm{NH}_{3}$ volatilization. In wet savanna ecosystems, Djougou and Lamto (respectively 8 and 7 cattle headskm ${ }^{-2}$ ) present moderate values of $\mathrm{NH}_{3}$ volatilization fluxes (respectively 2.5 and $2.3 \mathrm{kgNha}^{-1} \mathrm{yr}^{-1}$ ), comparable to other sources. Indeed, the contribution of $\mathrm{N}$ compounds emissions from 

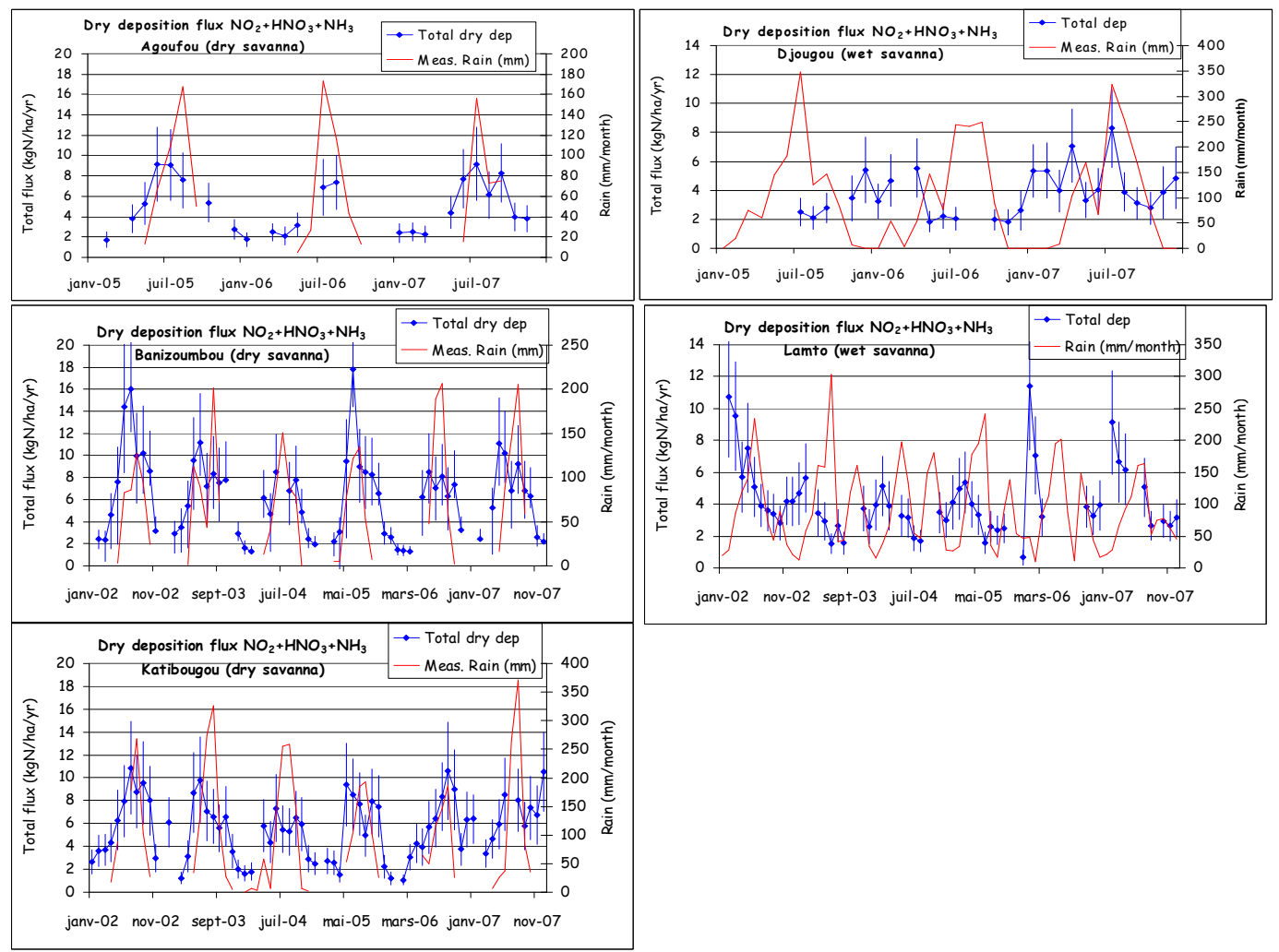

Fig. 4. Total gaseous dry deposition flux $\left(\mathrm{NH}_{3}+\mathrm{NO}_{2}+\mathrm{HNO}_{3}\right)$ in $\mathrm{kgNha}^{-1} \mathrm{yr}^{-1}$ and measured rain (mm.month $\left.{ }^{-1}\right)$ at Agoufou, Banizoumbou, Katibougou, Djougou and Lamto.

biomass burning in Djougou and Lamto (respectively 1.9 and $2.5 \mathrm{kgNha}^{-1} \mathrm{yr}^{-1}$ for $\mathrm{NO}_{\mathrm{x}}$ and 1.5 and $2.3 \mathrm{kgNha}^{-1} \mathrm{yr}^{-1}$ for $\mathrm{NH}_{3}$ ) is more important than in dry savanna sites. Biomass burning and volatilization contribution to total emission flux are inverted along the latitudinal gradient from north to south, as the available vegetation is more important, and the number of cattle headskm ${ }^{-2}$ is less important.

In Fig. 5b, the dry deposition flux of oxidized and reduced compounds is more important in Agoufou, Banizoumbou and Katibougou than in Djougou and Lamto, whereas the wet deposition flux increases from dry to wet savanna ecosystems. Wet deposition fluxes are correlated to rain amount and concentrations in precipitations. Obviously, wet deposition flux is larger if the rainfall is stronger and if the concentrations are more important. Annual means of wet deposition fluxes $\left(\mathrm{NH}_{4}^{+}+\mathrm{NO}_{3}^{-}\right)$are $2.35 \pm 1.88,2.14 \pm 0.67$, $3.40 \pm 0.75,3.53 \pm 0.70$, and $5.33 \pm 0.97 \mathrm{kgNha}^{-1} \mathrm{yr}^{-1}$ in Agoufou, Banizoumbou, Katibougou, Djougou and Lamto respectively. One should note that in spite of the large difference in precipitation quantity between the two extremes of this gradient, Agoufou (392 mm) and Lamto (1301 mm), the wet deposition flux is only twice in Lamto. Rain in Agoufou presents high concentrations in nitrate and ammonium (respectively 14 and $25 \mu$ eq. $1^{-1}$ ), larger than those measured in
Lamto (9 and $21 \mu$ eq. $1^{-1}$ of nitrate and ammonium respectively). The combination of annual rainfall depth and measured concentrations leads to a nitrogen wet deposition flux in Lamto only twice the one in Agoufou. The large quantity of rainfall, and above all the longer duration of the rain season in Lamto has a dilution effect on chemical species in rain.

The contribution of different sources of emission, together with the contribution of wet and dry deposition are presented in Fig. 6 for each site. In Agoufou, Banizoumbou and Katibougou (dry savannas), dry deposition is superior to wet deposition. The contribution of wet deposition increases in Djougou and Lamto, for the reasons invoked above. In Agoufou and Banizoumbou, as well as in Djougou and Lamto, emission fluxes are superior to deposition fluxes, by $3 \%, 8 \%, 6 \%$ and $2 \%$ respectively. In Katibougou, deposition fluxes are $7 \%$ superior to emission fluxes. Considering the range of uncertainty on total emission $(45 \%)$ and deposition $(25 \%)$ fluxes, these differences in the budgets in all sites are not significant enough, but could however lead to the conclusion that emission and deposition fluxes are quasi equivalent in wet and dry savannas, with a slight tendency for emission fluxes to be superior to deposition fluxes. The case of Katibougou is a transitional case: Katibougou is located at 

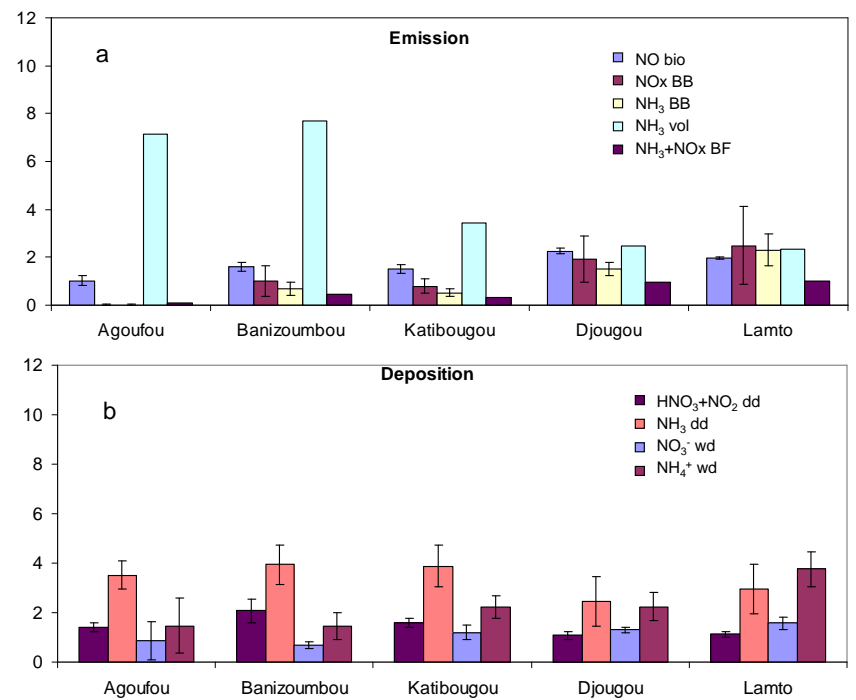

Fig. 5. Emission (a) and deposition (b) components of the atmospheric $\mathrm{N}$ budget in annual mean in $\mathrm{kgNha}^{-1} \mathrm{yr}^{-1}$ for the five IDAF stations for the years 2002 to 2007. bio = biogenic, $\mathrm{BB}=$ biomass burning, wd = wet deposition, $\mathrm{dd}=$ dry deposition, vol = volatilization, $\mathrm{BF}=$ biofuel. Error bars represent interannual variability. No error bars appear for $\mathrm{NH}_{3}$ volatilization and $\mathrm{BF}$ because of no interannual variability available for these data.

$12^{\circ} \mathrm{N}$, at the boundary between Sahel and Soudano-Sahelian region. The vegetation description is close to Sahelian vegetation, but the quantity of rainfall is more important. Wet and dry deposition fluxes are both substantial, and dominate sligthly total emission fluxes. The uncertainty applied on deposition fluxes (25\%), has been calculated only from quantifiable assumptions. In reality, dry deposition fluxes of $\mathrm{NH}_{3}$ do not take into account the compensation point concept, and an important additional uncertainty (not quantified in this work) should be applied on this contribution of the budget.

Figure 6 shows that total emission and deposition quantities are in the same order of magnitude for each site, with deposition fluxes of $7.25 \pm 2.60 \mathrm{kgNha}^{-1} \mathrm{yr}^{-1}$ in Agoufou, $8.16 \pm 1.84 \mathrm{kgNha}^{-1} \mathrm{yr}^{-1}$ in Banizoumbou, $8.87 \pm 1.59$ $\mathrm{kgNha}^{-1} \mathrm{yr}^{-1}$ in Katibougou, $7.07 \pm 0.98 \mathrm{kgNha}^{-1} \mathrm{yr}^{-1}$ in Djougou, 9.39 $\pm 1.07 \mathrm{kgNha}^{-1} \mathrm{yr}^{-1}$ in Lamto. Emission fluxes are $8.29 \pm 3.88 \mathrm{kgNha}^{-1} \mathrm{yr}^{-1}$ in Agoufou, $11.45 \pm 5.20 \mathrm{kgNha}^{-1} \mathrm{yr}^{-1}$ in Banizoumbou, $6.58 \pm 2.52$ $\mathrm{kgNha}^{-1} \mathrm{yr}^{-1}$ in Katibougou, $9.11 \pm 3.14 \mathrm{kgNha}^{-1} \mathrm{yr}^{-1}$ in Djougou, and $10.09 \pm 4.11 \mathrm{kgNha}^{-1} \mathrm{yr}^{-1}$ in Lamto. Though budgets seem equivalent from dry to wet savanna, this study has shown that a detailed description of processes of emission and deposition leads to different contribution of each component of the budget in the two types of ecosystems.

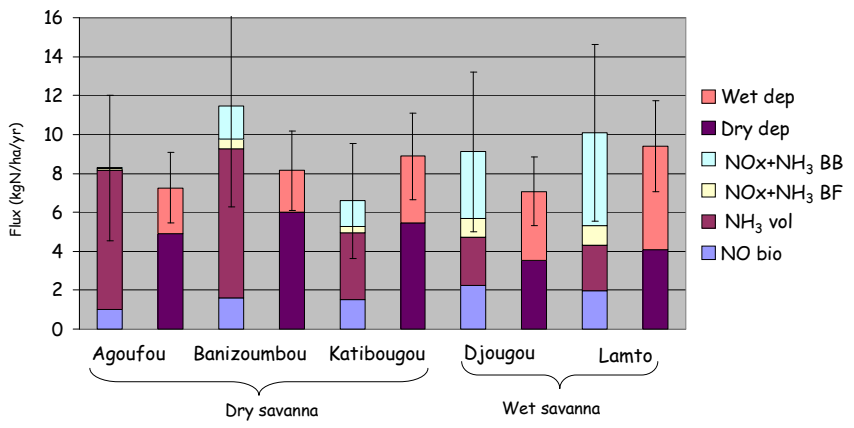

Fig. 6. Contribution of emission and deposition $\mathrm{N}$ fluxes in $\mathrm{kgNha}^{-1} \mathrm{yr}^{-1}$ for five stations in dry and wet savanna ecosystems. Error bars represent the total uncertainty of fluxes. $\mathrm{BB}=$ Biomass burning, $\mathrm{BF}=$ Biofuels. vol $=$ volatilization. For each site, first histogram is for emission, second is for deposition.

\section{Conclusions}

This study is based on original and unique data from remote and seldom explored regions. Satellite data, surface measurements and modelling results were merged to estimate the atmospheric reactive $\mathrm{N}$ cycle in West Africa, in five stations of the IDAF network: 3 stations in dry savanna ecosystem, 2 in wet savanna ecosystem, situated along a rainfall gradient from $15^{\circ} \mathrm{N}$ to $6^{\circ} \mathrm{N}$. The $\mathrm{N}$ cycle in dry savanna is closely linked to the precipitation cycle, itself conducted by the WAM climatic system: $\mathrm{N}$ is stored in the soil during the long dry season, and released to the atmosphere during the wet season (almost at the beginning) in the form of $\mathrm{NO}$ and $\mathrm{NH}_{3}$, and further wet and dry deposited in the form of $\mathrm{NH}_{3}$, $\mathrm{HNO}_{3}, \mathrm{NO}_{2}, \mathrm{NH}_{4}^{+}$and $\mathrm{NO}_{3}^{-}$. Wet and dry deposition are mainly associated to biomass burning, domestic fires, biogenic $\mathrm{NO}$ emissions and $\mathrm{NH}_{3}$ volatilization. In wet savanna the moisture content in soils is less variable because the rainfall amount is more important, and dry deposition is mostly influenced by biomass burning emissions. Wet deposition increases along the rainfall gradient from Agoufou to Lamto, mainly due to the quantity of rainfall. Fluxes are linked to the rainfall (in occurrence and quantity), and indirectly to the growing of the vegetation, through the $\mathrm{N}$ cycle in soils and in the atmosphere. It is therefore crucial in this part of the world to correctly represent the amount and occurrence of rain to impulse the right emissions and explain the subsequent deposition processes. No obvious tendency could have been assessed between the rainfall variability from year to year and the corresponding variability in $\mathrm{N}$ deposition and emission loads. Rainfall interannual variability has been evaluated to be $15 \%$ at the most, whereas total emission flux inter annual variability is maximum $18 \%$ (taking into account variable fluxes only), dry deposition flux variability ranges between 15 and $28 \%$, and wet deposition variability is around $20 \%$ for every site. The short period of the study (6 years only), 
and above all the fact that the major contribution in the emission budget is held in constant fluxes $\left(\mathrm{NH}_{3}\right.$ volatilization), prevented to find a common tendency between the quantity of rainfall and the magnitude in emission and deposition fluxes across the years. Total budget gives emission and deposition loads between 6 and $11 \mathrm{kgNha}^{-1} \mathrm{yr}^{-1}$, dominated by $\mathrm{NH}_{3}$ whatever the type of ecosystem. Total emission and deposition fluxes are in the same range whatever the site, but the contribution of each emission source and each deposition process is different between dry and wet savanna. Despite numerous uncertainties (linked to the fact that results mostly follow from modelling), this study has allowed a comparison between emission and deposition $\mathrm{N}$ fluxes magnitude and leading processes in two different types of ecosystems of west Africa, responsible for $\mathrm{N}$ load in the atmosphere, in regions where few data are available.

Acknowledgements. This work is part of the IDAF (IGAC/DEBITS/AFRICA) and AMMA (African Monsoon Multidisciplinary Analysis) projects. IDAF has been supported by the "Institut National des Sciences de LUnivers" within the framework of the ORE programme (Observatoire de Recherche en Environnement). Based upon a French initiative, the AMMA project is now supported by an international scientific group including a large number of agencies, especially from France, the United Kingdom, the United States and Africa. It has been the beneficiary of a major financial contribution from the European Communitys Sixth Framework Research Programme (FP6), see www.amma-international.org $\langle$ htt://-www.amma-international.org $\rangle$. We thank the IRD (Institut pour la Recherche et le Developpement) in Bamako for logistical support. We also thank all local field technicians of the IDAF network, and P. Castéra and E. Gardrat from the analytical chemistry lab in Toulouse for all chemical analysis.

\section{Edited by: D. F. Prieto}

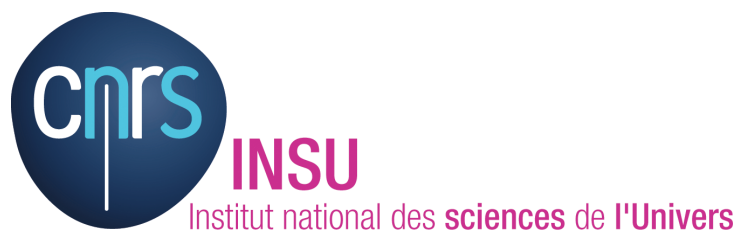

The publication of this article is financed by CNRS-INSU.

\section{References}

Adon, M., Galy-Lacaux, C., Yoboué, V., Delon, C., Lacaux, J. P., Castera, P., Gardrat, E., Pienaar, J., Al Ourabi, H., Laouali, D., Diop, B., Sigha-Nkamdjou, L., Akpo, A., Tathy, J. P., Lavenu, F., and Mougin, E.: Long term measurements of sulfur dioxide, nitrogen dioxide, ammonia, nitric acid and ozone in Africa using passive samplers, Atmos. Chem. Phys., 10, 7467-7487, doi:10.5194/acp-10-7467-2010, 2010.
Andreae, M. O. and Merlet, P.: Emission of trace gases and aerosols from biomass burning, Global Biogeochem. Cy., 15, 955-966, 2001.

Assamoi, E. M. and Liousse, C.: A new inventory for two-wheel vehicle emissions in West Africa for 2002, Atmos. Environ. 44, 3985-3996, 2010.

Barger, N. N, Belnap, J., Ojima, D. S., and Mosier, A.: NO gas loss from biologically crusted soils in Canyonlands National Park, Utah, Biogeochemistry, 75, 373-391, 2005.

Barnes, D. F., Krutilla, K., and Hyde, W.: The urban energy transition: Energy, poverty, and the environment in the developing world, draft report, World Bank, Washington, D. C., 2001.

Boone A., De Rosnay, P., Balsamo, G., Beljaars, A., Chopin, F., Decharme, B., Delire, C., Ducharne, A., Gascoin, S., Grippa, M., Guichard, F., Gusev, Y., Harris, P., Jarlan, L., Kergoat, L., Mougin, E., Nasonova, O., Norgaard, A., Orgeval, T., Ottl, C., Poccard-Leclerq, I., Polcher, J., Sandholt, I., Saux-Picart, S., Taylor, C., and Xue, Y.: The AMMA Land Surface Model Intercomparison Project (ALMIP), Bull. Amer. Meteor. Soc., 12, 1865-1880, 2009.

Boulain N., Cappelaere, B., Ramier, D., Issoufou, H. B. A., Halilou, O., Seghieri, J., Guillemin, F., Oi, M., Gignoux, J., and Timouk, F.: Towards an understanding of coupled physical and biological processes in the cultivated Sahel -2 . Vegetation and carbon dynamics, J. Hydrol, 375, 190-203, 2009.

Bouwman A. F., Lee, D. S., Asman, W. A. H., Dentener, F. J., Van Der Hoek, K. W., and Olivier, J. G. J.: A Global High-Resolution Emission Inventory for Ammonia, Global Biogeochem. Cy., 11, 561-587, 1997.

Bouwman, A. F. and Van Der Hoek, K. W.: Scenarios of animal waste production and fertilizer use and associated ammonia emission for the developping countries, Atmos. Env., 31, 40954102, 1997.

Bouwman, A. F., Boumans, L. J., and Batjes, N. H.: Estimation of global $\mathrm{NH}_{3}$ volatilization loss from synthetic fertilizers and animal manure applied to arable lands and grasslands, Glob. Biogeochem. Cycles, 16, 1024, doi:10.1029/2000GB001389, 2002a

Brummer C., Bruggemann, N., Butterbach-Bahl, K., Falk, U., Szarzynski, J., Vielhauer, K., Wassmann, R., and Papen, H.: Soil-Atmosphere Exchange of $\mathrm{N}_{2} \mathrm{O}$ and $\mathrm{NO}$ in Near-Natural Savanna and Agricultural Land in Burkina Faso (W. Africa), Ecosystems, 11, 582-600, 2008.

Butterbach-Bahl, K., Stange, F., Papen, H., and Li, C.: Regional inventory of nitric oxide and nitrous axide emissions for forest soils of southeast Germany using the biogeochemical model PnET-NDNDC, J. Geophys. Res. 106, 34155-34166, 2001.

Cardenas L., Rondon, A., Johansson, C., and Sanhueza, E.: Effects of the soil moisture, temperature, and N-nutrient in the NO emissions from acidic tropical savannah soils under dry and wet season conditions, J. Goephys. Res., 98, 14783-14790, 1993.

Chen, Y., Randerson, J. T., Van Der Werf, G. R., Morton, D. C., Mu, M., and Kasibhatla, P. S.: Nitrogen deposition in tropical forests from savanna and deforestation fires, Global Change Biol., 16, 2024-2038, 2010.

Coetsee C., Bond, W. J., and February, E. C.: Frequent fire affects soil nitrogen and carbon in an African savanna by changing woody cover, Oecologia, 162, 1027-1034, 2010.

Davidson, E. A., Matson, P. A., Vitousek, P. M., Riley, R., Dunkin, K., Garca-Mendez G. and Maass J. M., Processes regulating soil 
emissions of $\mathrm{NO}$ and $\mathrm{N}_{2} \mathrm{O}$ in a seasonally dry tropical forest, Ecology, 74, 130-139, 1993.

Davidson, E. A., Vitousek, P. M., Matson, P. A., Riley, R., GarcaMendez G. and Maass, J. M., Soil emissions of nitric oxide in a seasonally dry tropical forest of Mexico. J. Geophys. Res., 96, 439-445, 1991.

Delmas, R. A., Loudjani, P., Podiare, A., and Menaut, J. C.: Biomass burning in Africa: An assessment of annually burnt biomass, in Glbal Biomass burning, edited by: Levine, J. S., 126-133, MIT Press, Cambridge, 1991.

Delmas, R., Lacaux, J. P., Menaut, J. C., Abbadie, L., LeRoux, X., Helas, G., and Lobert, J.: Nitrogen compound emission from biomass burning in tropical African savanna FOS/DECAFE 1991 Experiment (Lamto, Ivory Coast), J. Atmos. Chem., 22, 175-193, 1995.

Delon, C., Serça, D., Boissard, C., Dupont, R., Dutot, A., Laville, de Rosnay, P., and Delmas, R.: Soil NO emissions modelling using artificial neural network, Tellus B, 59B, 502-513, 2007.

Delon, C., Reeves, C. E., Stewart, D. J., Sera, D., Dupont, R., Mari, C., Chaboureau, J.-P., and Tulet, P.: Biogenic nitrogen oxide emissions from soils impact on $\mathrm{NO}_{\mathrm{x}}$ and ozone over West Africa during AMMA (African Monsoon Multidisciplinary Experiment): modelling study, Atmos. Chem. Phys., 8, 2351-2363, doi:10.5194/acp-8-2351-2008, 2008.

Delon, C., Galy-Lacaux, C., Boone, A., Liousse, C., Sera, D., Adon, M., Diop, B., Akpo, A., Lavenu, F., Mougin, E., and Timouk, F.: Atmospheric nitrogen budget in Sahelian dry savannas, Atmos. Chem. Phys., 10, 2691-2708, doi:10.5194/acp-10-26912010, 2010.

de Montalembert, M. R. and Clement, J.: Fuelwood supplies in the developing countries, FAO For. Pap. 42, Food and Agric. Org., Rome, 1983.

Duncan, B. N., R. V. Martin, A. C. Staudt, R. Yevich, and J. A. Logan, Interannual and seasonal variability of biomass burning emissions constrained by satellite observations, J. Geophys. Res., 108, 4100, doi:10.1029/2002JD002378, 2003.

Feig, G. T., Mamtimin, B., and Meixner, F. X.: Soil biogenic emissions of nitric oxide from a semi-arid savanna in South Africa, Biogeosciences, 5, 1723-1738, doi:10.5194/bg-5-17232008, 2008.

Flechard, C. R., Nemitz, E., Smith, R. I., Fowler, D., Vermeulen, A. T., Bleeker, A., Erisman, J. W., Simpson, D., Zhang, L., Tang, Y. S., and Sutton, M. A.: Dry deposition of reactive nitrogen to European ecosystems: a comparison of inferential models across the NitroEurope network, Atmos. Chem. Phys., 11, 2703-2728, doi:10.5194/acp-11-2703-2011, 2011.

Galloway, J. N., Townsend, A. R., Erisman, J. W., Bekunda, M., Cai, Z., Freney, J. R., Martinelli, L. A., Seitzinger, S. P., and Sutton, M. A.: Transformation of the Nitrogen Cycle: Recent Trends, Questions, and Potential Solutions, Science, 320, 889892, 2008

Galy-Lacaux C. and Modi, A. I.: Precipitation chemistry in the Sahelian savanna in Niger, Africa, J. Atmos. Chem., 30, 319-343, 1998.

Galy-Lacaux, C., Laouali, D., Descroix, L., Gobron, N., and Liousse, C.: Long term precipitation chemistry and wet deposition in a remote dry savanna site in Africa (Niger), Atmos. Chem. Phys., 9, 1579-1595, doi:10.5194/acp-9-1579-2009, 2009.

Hanson, P. J. and Lindberg, S. E.: Dry deposition of reactive nitro- gen compounds: a review of leaf, canopy and non-foliar measurements, Atmos. Environ., 25A, 1615-1634, 1991.

Hartley, A. E. and Schlesinger, W. H.: Environmental controls on nitric oxide emission from northern Chihuahuan desert soils, Biogeochemistry, 50, 279-300, 2000.

Hill, K. A., Shepson, P. B., Galbavy, E. S., and Anastasio, C.: Measurement of wet deposition of inorganic and organic nitrogen in a forest environment, J. Geophys. Res., 110, G02010, doi:10.1029/2005JG000030, 2005.

Hiernaux P., Fernandez-Rivera, S., Schlecht, E., Turner, M. D., and Williams, T. O.: Livestock-mediated nutrient transfers in Sahelian agro-ecosystems, edited by: Renard, G., Neef, A., Becker, K., and von Oppen, M., Soil fertility management in West African land use systems, Niamey, Niger, 4-8.03.97, Margraf Verlag, Weikersheim, Germany, 339-347, 1998.

Hiernaux, P. and Turner, M. D.: The influence of farmer and pastoralism management practices on desertification processes in the Sahel, in: Global desertification: do humans cause deserts?, edited by: Reynolds, J. F. and Stafford Smith, D. M., Dahlem University Press, Berlin, 135-148, 2002.

Jaeglé, L., Martin, R. V., Chance, K., Steinberger, L., Kurosu, T. P., Jacob, D. J., Modi, A. I., Yoboué, V., Sigha-Nkamdjou, L., and Galy-Lacaux, C.: Satellite mapping of rain-induced nitric oxide emissions from soils, J. Geophys. Res., 109, D21310, doi:10.1029/2003JD004406, 2004.

Junker, C. and Liousse, C.: A global emission inventory of carbonaceous aerosol from historic records of fossil fuel and biofuel consumption for the period 1860-1997, Atmos. Chem. Phys., 8, 1195-1207, doi:10.5194/acp-8-1195-2008, 2008.

Kaptué, T. A. T., Roujean, J. L., and Faroux, S.: ECOCLIMAP II: an ecosystem classification and land surface parameter database of Western Africa at $1 \mathrm{~km}$ resolution for the AMMA project, Remote Sens. Environ., 114, 961-976, 2010.

Lebel, T. and Ali, A.: Recent trends in the Central and Western Sahel rainfall regime (1990-2007), J. Hydrol., 375, 52-64, 2009.

Le Roux, X., Abbadie, L., Lensi, R., and Serça, D.: Emission of nitrogen monoxide from African tropical ecosystems: Control of emission by soil characteristics in humid and dry savannas of West Africa, J. Geophys. Res., 100, 23133-23142, 1995.

Liousse, C., Guillaume, B., Grégoire, J. M., Mallet, M., Galy, C., Pont, V., Akpo, A., Bedou, M., Castra, P., Dungall, L., Gardrat, E., Granier, C., Konaré, A., Malavelle, F., Mariscal, A., Mieville, A., Rosset, R., Serça, D., Solmon, F., Tummon, F., Assamoi, E., Yoboué, V., and Van Velthoven, P.: Updated African biomass burning emission inventories in the framework of the AMMAIDAF program, with an evaluation of combustion aerosols, Atmos. Chem. Phys., 10, 9631-9646, doi:10.5194/acp-10-96312010, 2010.

Loubet B.,Laville, P., Lehuger, S., Larmanou, E., Flechard, C., Mascher, N., Genermont, S., Roche, R., Ferrara, R. M., Stella, P., Personne, E., Durand, B., Decuq, C., Flura, D., Masson, S., Fanucci, O., Rampon, J. N., Siemens, J., Kindler, R., Gabrielle, B., Schrumpf, M., and Cellier, P.: Carbon, nitrogen and greenhouse gases budgets over a four years crop rotation in northern France, Plant Soil, 343, 109-137, doi:10.1007/s11104-0110751-9, 2011.

Mace, K. A., Kubilay, N., and Duce, R. A.: Organic nitrogen in rain and aerosol in the eastern Mediterranean atmosphere: An association with atmospheric dust, J. Geophys. Res., 108, 4320, 
doi:10.1029/2002JD002997, 2003.

Mari, C. H., Cailley, G., Corre, L., Saunois, M., Attié, J. L., Thouret, V., and Stohl, A.: Tracing biomass burning plumes from the Southern Hemisphere during the AMMA 2006 wet season experiment, Atmos. Chem. Phys., 8, 3951-3961, doi:10.5194/acp-8-3951-2008, 2008.

Martin, R. E., Scholes, M. C., Mosier, A. R., Ojima, D. S., Holland, E. A., and Parton, W. J.: Controls on annual emissions of nitric oxide from soils of the Colorado shortgrass steppe, Global Biogeochem. Cycles, 12, 81-91, 1998.

Matson, P. A., McDowell, W. H., Towsend, A. R., and Vitousek, P. M.: The globalization of $\mathrm{N}$ deposition: ecosystem consequences in tropical environments, Biogeochemistry, 46, 67-83, 1999.

Matt, D. R. and Meyers, T. P.: On the use of the inferential technique to estimate dry deposition of $\mathrm{SO}_{2}$, Atmos. Environ, 27A, 493-501, 1993.

McCalley, C. K. and Sparks, J. P.: Controls over nitric oxide and ammonia emissions from Mojave Desert soils, Oecologia, 156, 871-881, 2008.

Meixner, F. X., Fickinger, T., Marufu, L., Serça, D., Nathaus, F. J., Makina, E., Mukurumbira, L., and Andreae, M. O.: Preliminary results on nitric oxide emission from a southern African savanna ecosystem, Nutr. Cycling Agroecosyst., 48, 123-138, 1997.

Meixner, F. X. and Yang, W. X.: Biogenic emissions of nitric oxide and ditrous oxide from arid and semi-arid land, Dryland Ecohydrology, edited by: DÓdoroco, P. and Porporato, A., by Kluwer Academic Publishers B.V., Dordrecht, The Netherlands, 23-46, 2004.

Menaut, J. C., Abbadie, L., and Vitousek, P. M.: Nutrient and organic matter dynamics in tropical ecosystems, in Fire in the Environment: The Ecological, Atmospheric, and Climatic Importance of Vegetation Fires, edited by: Crutzen P. J. and Goldammer, J. G., 219-230, John Wiley, New York, 1993.

Miller, A. E., Schimel, J. P., Meixner, T., Sickman, J. O., and Melack, J. M.: Episodic rewetting enhances carbon and nitrogen release from chaparral soils, Soil Biol. Biochem., 37, 21952204, 2004.

Mosier, A., Kroeze, C., Nevison, C., Oenema, O., Seitzinger, S., and van Cleemput, O.: Closing the global $\mathrm{N}_{2} \mathrm{O}$ budget: nitrous oxide emissions through the agricultural nitrogen cycle, Nutr. $\mathrm{Cy}$. Agroecosys., 52, 225-248, 1998.

Mougin, E., Hiernaux, P., Kergoat, L., Grippa, M., De Rosnay, P., Timouk, F., Le Dantec, V., Demarez, V., Arjounin, M., Lavenu, F., Soumaguel, N., Ceschia, E., Mougenot, B., Baup, F., Frappart, F., Frison, P. L., Gardelle, J., Gruhier, C., Jarlan, L., Mangiarotti, S., Sanou, B., Tracol, Y., Guichard, F., Trichon, V., Diarra, L., Soumaré, A., Koité, M., Dembélé, F., Lloyd, C., Hanan, N. P., Damesin, C., Delon, C., Serça, D., Galy-Lacaux, C., Seghiéri, J., Becerra, S., Dia, H., Gangneron, F., and Mazzega, P.: The AMMA-CATCH Gourma observatory site in Mali: Relating climatic variations to changes in vegetation, surface hydrology, fluxes and natural resources, J. Hydrology, AMMA-CATCH Special issue, 375, 14-33, 2009.

Munger, J. W., Fan, S.-M., Bakwin, P. S., Goulden, M. L., Goldstein, A. H., Colman, A. S., and Wofsy, S. C.: Regional budgets for nitrogen oxides from continental sources: Variations of rates for oxidation and deposition with season and distance from source regions, J. Geophys. Res., 103, 8355-8368, 1998.

Munro, P. E., Inhibition of nitriflers by grass root extracts., J. Appl.
Ecol., 3, 231-238, 1966.

Noilhan, J. and Mahfouf, J.-F.: The ISBA land surface parameterization scheme. Glob. Planet. Change, 13, 145-159, 1996.

Poth, M., Anderson, I. C., Miranda, H. S., Miranda, A. C., and Riggan, P. J.: The magnitude and persistence of soil $\mathrm{NO}, \mathrm{N}_{2} \mathrm{O}$, $\mathrm{CH}_{4}$, and $\mathrm{CO}_{2}$ fluxes from burned tropical savanna in Brazil, Global Biogeochem. Cycles, 9, 503-513, 1995.

Sauvage, B., Thouret, V., Cammas, J.-P., Brioude, J., Nedelec, P., and Mari, C.: Meridional ozone gradients in the African upper troposphere, Geophys. Res. Lett. 34, 03817, doi:10.1029/2006GL028542, 2007.

Schaeffer, S. M., Billings, S. A., and Evans, R. D.: Responses of soil nitrogen dynamics in a Mojave desert ecosystem to manipulations in soil carbon and nitrogen availability, Oecologia, 134, 547-553, 2003.

Schlecht, E. and Hiernaux, P.: Beyond adding up inputs and outputs: process assessment and upscaling in modelling nutrient flows, Nutr. Cy. Agroecosys., 70, 303-319, 2004.

Scholes, M. C., Martin, R., Scholes, R. J., Parsons, D., and Winsted, E.: $\mathrm{NO}$ and $\mathrm{N}_{2} \mathrm{O}$ emissions from savanna soils following the first simulated rains of the season, Nutr. Cycl. Agroecosyst., 48, 115122, 1997.

Serça, D., Delmas, R., Jambert, C., and Labroue, L.: Emissions of nitrogen oxides from equatorial rain forest in central Africa: Origin and regulation of NO emission from soils, Tellus B, 46, 143-254, 1994.

Serça, D., Delmas, R., Le Roux, X., Parsons, D. A. B., Scholes, M. C., Abbadie, L., Lensi, R., Ronce, O., and Labroue, L.: Comparison of nitrogen monoxide emissions from several African tropical ecosystems and influence of season and fire, Global Biogeochem. Cycles 12, 637-651, 1998.

Stewart, D. J., Taylor, C. M., Reeves, C. E., and McQuaid, J. B.: Biogenic nitrogen oxide emissions from soils: impact on $\mathrm{NO}_{\mathrm{x}}$ and ozone over west Africa during AMMA (African Monsoon Multidisciplinary Analysis): observational study, Atmos. Chem. Phys., 8, 2285-2297, doi:10.5194/acp-8-2285-2008, 2008.

Stohl, A., Williams, E., Wotawa, G., and Kromp-Kolb, H.: A European inventory of soil nitric oxide emissions and the effect of these emissions on the photochemical formation of ozone, Atmos. Environ., 30, 22, 3741-3755, 1996.

Sutton, M. A., Nemitz, E., Erisman, J. W., Beier, C., Butterbach Bahl, K., Cellier, P., de Vries, W., Cotrufo, F., Skiba, U., Di Marco, C., Jones, S., Laville, P., Soussana, J. F., Loubet, B., Twigg, M., Famulari, D., Whitehead, J., Gallagher, M. W., Neftel, A., Flechard, C. R., Herrmann, B., Calanca, P. L., Schjoerring, J. K., Daemmgen, U., Horvath, L., Tang, Y. S., Emmett, B. A., Tietema, A., Penuelas, J., Kesik, M., Brueggemann, N., Pilegaard, K., Vesala, T., Campbell, C. L., Olesen, J. E., Dragosits, U., Theobald, M. R., Levy, P., Mobbs, D. C., Milne, R., Viovy, N., Vuichard, N., Smith, J. U., Smith, P., Bergamaschi, P., Fowler, D., and Reis, S.: Challenges in quantifying biosphere-atmosphere exchange of nitrogen species, Env. Poll. 150, 125-139, 2007.

Thouret, V., Saunois, M., Minga, A., Mariscal, A., Sauvage, B., Solete, A., Agbangla, D., Nédélec, P., Mari, C., Reeves, C. E., and Schlager, H.: An overview of two years of ozone radio soundings over Cotonou as part of AMMA, Atmos. Chem. Phys., 9, 6157-6174, doi:10.5194/acp-9-6157-2009, 2009.

van der Werf, G. R., Randerson, J. T., Giglio, L., Collatz, G. J., 
Kasibhatla, P. S., and Arellano Jr., A. F.: Interannual variability in global biomass burning emissions from 1997 to 2004, Atmos. Chem. Phys., 6, 3423-3441, doi:10.5194/acp-6-3423-2006, 2006.

Wesely, M. L.: Parameterization of surface resistances to gaseous dry deposition in regional-scale numerical models, Atmos. Environ., 23, 1293-1304, 1989.

Whitall D., Hendrickson, B., and Paerl, H.: Importance of atmospherically deposited nitrogen to the annual nitrogen budget of the Neuse River estuary, North Carolina, Environ. Int., 29, 393399, 2002.

Williams, C. A., Hanan, N. P., Baker, I., Collatz, G. J., Berry, J., and Denning, A. S.: Interannual variability of photosynthesis across Africa and its attribution, J. Geophys. Res., 113, G04015, doi:10.1029/2008JG000718, 2008.

Wolff, V., Trebs, I., Foken, T., and Meixner, F. X.: Exchange of reactive nitrogen compounds: concentrations and fluxes of total ammonium and total nitrate above a spruce canopy, Biogeosciences, 7, 1729-1744, doi:10.5194/bg-7-1729-2010, 2010.
Yevich, R. and Logan, J. A.: An assessment of biofuel use and burning of agricultural waste in the developing world, Global Biogeochemical Cycles, 17, 4:1095, doi:10.1029/2002GB001952, 2003.

Yienger, J. J. and Levy II, H.: Empirical model of global soil biogenic $\mathrm{NO}_{\mathrm{x}}$ emissions, J. Geophys. Res., 100, 11447-11464, 1995.

Vila-Guerau de Arellano, J. and Duynkerke, P. G.: Influence of chemistry on the flux-gradient relationships for the $\mathrm{NO}-\mathrm{O}_{3}-\mathrm{NO}_{2}$ system, Bound. Lay. Meteorol., 61, 375-387, 1992.

Yoboué, V., Galy-Lacaux, C., Lacaux, J. P., and Sibué, S.: Rainwater Chemistry and Wet Deposition over the Wet Savanna Ecosystem of Lamto (Côte d'Ivoire), J. Atmos. Chem., 52, 117-141, 2005.

Zhang, L., Brook, J. R., and Vet, R.: A revised parameterization for gaseous dry deposition in air-quality models, Atmos. Chem. Phys., 3, 2067-2082, doi:10.5194/acp-3-2067-2003, 2003.

Zhang L., Wright, L. P., and Asman, W. A. H.: Bi directional air surface exchange of atmospheric ammonia: A review of measurements and a development of a big leaf model for applications in regional scale air quality models, J. Geophys. Res., 115, D20310, doi:10.1029/2009JD013589, 2010. 